\title{
PORESKI UČINAK NA UKUPNI TROŠAK PLATE
}

\author{
Luka Lj. Zloporubović i Ljubomir M. Radević
} Ministarstvo odbrane Republike Srbije društva. Od egzistencijalnog obnavljanja utrošene psihofizičke radne snage, poboljšanja materijalnih uslova za život, obezbeđenja penzionog i zdravstvenog osiguranja, preko stimulacije za boljim rezultatima, inoviranju poslovnih aktivnosti, usvajanju novog znanja i daljeg usavršavanja, kroz prestižni društveno-socijalni status, kao efikasno sredstvo u kreiranju korporativne politike i raspodele dobiti, korišćenja poreskih rasterećenja i poreskih kredita u granicama pravnih okvira, a u sadašnjem makroekonomskom okruženju i kao novoustrojeni instrument kontrolisanja javne potrošnje.

Ključne reči: zarada, plata, metode obračuna plate, bruto princip obračuna plate, neto princip obračuna plate

\section{Uvod}

\ poslednjoj dekadi, nastala je velika razuđenost u organizaciji i normativnoj uređenosti zarada u državnoj upravi. Trenutno postoji nekoliko sistema obračuna zarade kod budžetskih korisnika koji su uspostavljani zalaganjem pojedinih interesnih grupa uz odsustvo sveobuhvatne analize i strategije. Dosadašnjim nominalnim regulisanjem mase zarada u javnom sektoru, površno se pribegavalo postizanju brzih i opipljivih koristi u kratkom vremenskom roku, dok se potreba suštinskog reformisanja i nivelacije razlika u zaradama između zaposlenih na istim ili sličnim poslovima u različitim državnim organima i službama odlagala, usled političkih i socijalnih komplikacija.

lako zarada pored značajne stavke rashoda u bilansu predstavlja i osnovni motivacioni faktor u unapređenju individualnih i grupnih rezultata, zbog čega se uostalom, pitanju zarade pridaje posebna pažnja do najvišeg nivoa upravljanja u privrednom ili vanprivrednom subjektu, nastavljaju se manifestovati organizacioni i konceptualni previdi u uspostavljenim sistemima obračuna zarada kao posledica kratkovidog sagledavanja uzročnoposledičnih veza ad-hoc rešenja.

Čak i tokom stagnacije realnog nivoa zarada, postoji prostor za poboljšanjem sistema obračuna i administracije zarada. Tek kada se odgovarajućim merama stvori mehanizam da svaka promena u poreskom sistemu, ili u sistemu obračuna zarada, ili u sistemu penzionog i socijalnog osiguranja indirektno doprinosi razvoju segmenata ostalih sistema, mogu se očekivati sinergetski efekti u konsolidaciji javnih finansija. 


\section{Osvrt na postojeće metode obračuna plate kod budžetskih korisnika}

Plata je osnovna kategorija primanja koju lice u radnom odnosu kod budžetskog korisnika zaradi po osnovu rada u uobičajenom kalendarskom razdoblju od mesec dana. Računovodstveno posmatrano, plata je rashod u bruto iznosu koji pored iznosa za isplatu licu inkorporira i sumu poreza i doprinosa na teret zaposlenog koji su uključeni u platu, pri čemu, pored plate nastaje i rashod po osnovu doprinosa na teret poslodavca.

Trenutno, za obračun i isplatu plata zaposlenih kod budžetskih korisnika primenjuje se veliki broj zakonskih i podzakonskih propisa, što ima za posledicu, da se obavljanje istovrsnih poslova različito vrednuje u državnim organima i institucijama. Cilj donošenja Zakona o sistemu plata zaposlenih u javnom sektoru („Službeni glasnik RS“, broj 18/16) sastoji se u uspostavljanju jedinstvene osnovice, merila i kataloga radnih mesta, koji će ukinuti različit iznos plate za obavljanje istih poslova pod istim uslovima i rizikom. Metode obračuna plate, koje će se dalje razmatrati u ovom radu, nisu izmenjene novim zakonom.

Sa aspekta načina obračuna plate, od 2008. godine, postoje dve metode po kojima se obračunavaju plate zaposlenih kod budžetskih korisnika: 1) metoda obračuna plate po neto osnovici i 2) metoda obračuna plate po bruto osnovici. U cilju analize metode obračuna plate po neto osnovici razmotriće se obračun plate državnih službenika i nameštenika, dok će se metoda obračuna plate po bruto osnovici preispitati u primeru obračuna plate profesionalnih pripadnika Vojske.

\section{Obračun plate državnih službenika i nameštenika}

\section{Determinante plate državnog službenika ili nameštenika}

Za obračun i isplatu plata državnim službenicima i nameštenicima trenutno se primenjuje Zakon o platama državnih službenika i nameštenika (u daljem tekstu: Zakon o plati DSN).

Saglasno opštem modelu plata zaposlenih kod budžetskih korisnika, platu državnih službenika i nameštenika čini osnovna plata sa uvećanjima (dodaci na platu) koji se ostvaruju pod određenim uslovima, pri čemu se u platu uračunavaju i porezi i doprinosi koji se plaćaju iz plate (Zakon o plati DSN, čl. 2.).

Mesečna osnovna plata državnog službenika i nameštenika dobija se kao proizvod koeficijenta (za položaj ili izvršilačkog radnog mesta za državnog službenika odnosno koeficijenta radnog mesta za državnog nameštenika) sa osnovicom za obračun plate (Zakon o plati DSN, čl. 4. stav 1. i čl. 7.).

Za sve državne službenike i nameštenike primenjuje se ista osnovica za obračun plate koja se utvrđuje svake godine zakonom o budžetu. Trenutno je utvrđena osnovica za obračun i isplatu plata za državne službenike i nameštenike u neto iznosu 17.101,29 dinara sa pripadajućim porezom i doprinosima za obavezno socijalno osiguranje (Zakon o budžetu Republike Srbije, 2016). Postavlja se pitanje, koliko iznosi osnovica za obračun plate državnih službenika i nameštenika u bruto iznosu? U nastavku će biti dalje razmatrano. 
Dakle, uzimajući u obzir način kako se utvrđuje mesečna osnovna plata za državne službenike i nameštenike, uočava se, da mesečna osnovna plata državnih službenika i nameštenika koji rade puno radno vreme u mesecu ostaje nepromenjena bez obzira na broj radnih dana odnosno časova u mesecu, s tim da se osnovna plata po radnom času u tekućem mesecu menja obrnuto proporcionalno odnosu ukupnog broja radnih sati u tekućem mesecu naspram ukupnog broja radnih sati u prethodnom mesecu.

Tabela 1 - Obrnut odnos kretanja vrednosti osnovne plate po satu u odnosu na dinamiku mesečnog fonda radnih sati

\begin{tabular}{|c|c|c|c|c|c|c|c|c|}
\hline $\mathrm{n}$ & $\begin{array}{l}\text { Koefi- } \\
\text { cijent }\end{array}$ & $\begin{array}{c}\text { neto } \\
\text { osnovica }\end{array}$ & $\begin{array}{c}\text { osnovna } \\
\text { plata } \\
\text { (kolona 1 x } \\
\text { kolona 2) }\end{array}$ & $\begin{array}{c}\text { fond } \\
\text { radnih } \\
\text { sati u } \\
\text { mesecu }\end{array}$ & $\begin{array}{c}\text { osnova } \\
\text { plata po } \\
\text { radnom } \\
\text { času } \\
\text { (kolona 3 / } \\
\text { kolona 4) }\end{array}$ & $\begin{array}{c}\text { odnos fonda } \\
\text { sati u tekućem } \\
\text { mesecu } \\
\text { naspram } \\
\text { fonda sati u } \\
\text { prethodnom } \\
\text { mesecu } \\
\text { (kolona } 4 \text { red } \\
n \\
\text { / kolona } 4 \text { red } \\
n-1 \text { ) }\end{array}$ & $\begin{array}{c}\text { Obrnuto } \\
\text { proporcionalan } \\
\text { broj u odnosu na } \\
\text { broj u koloni } 6 \\
\text { (1/ kolona 6) }\end{array}$ & $\begin{array}{l}\text { osnovna plata po } \\
\text { času u tekućem } \\
\text { mesecu u odnosu } \\
\text { na osnovnu platu } \\
\text { po času u } \\
\text { prethodnom } \\
\text { mesecu } \\
\text { (kolona } 5 \text { red n } \\
\text { / kolona } 5 \text { red } n-1 \text { ) }\end{array}$ \\
\hline & 1 & 2 & 3 & 4 & 5 & 6 & 7 & 8 \\
\hline 1 & $2,93^{*}$ & $17.101,29$ & $50.106,78$ & 184 & 92,94 & - & - & - \\
\hline 2 & $2,93^{*}$ & $17.101,29$ & $50.106,78$ & 160 & 106,88 & 0,869565217 & 1,15 & 1,15 \\
\hline 3 & $2,93^{*}$ & $17.101,29$ & $50.106,78$ & 176 & 97,17 & 1,1 & 0,909090909 & 0,909090909 \\
\hline 4 & $2,93^{*}$ & $17.101,29$ & $50.106,78$ & 168 & 101,79 & 0,954545455 & 1,047619048 & 1,047619048 \\
\hline
\end{tabular}

${ }^{*}$ Koeficijent je nasumice odabran iz tabele u članu 13. Zakona o plati DSN

Dinamika mesečnog fonda sati odnosno kretanje osnovne plate po radnom satu implicira prosečno mesečno uvećanje ili smanjenje dodataka na platu što se u situaciji ograničenog budžeta posebno prati u cilju blagovremenog preduzimanja korektivnih mera.

Koeficijenti za državne službenike se razvrstavaju naspram platnih grupa namenjenih za položaje i platnih grupa namenjenih za izvršilačka radna mesta. Položaji odnosno koeficijenti za položaj su raspoređeni od prve do pete platne grupe, a izvršilačka radna mesta i odnosni koeficijenti od šeste do trinaeste platne grupe, s tim da se u okviru svake platne grupe gde su raspoređena izvršilačka radna mesta nalazi po osam platnih razreda. Od prve do pete platne grupe nema platnih razreda (Zakon o plati DSN, čl. 9).

Svaki koeficijent za položaj i koeficijent za izvršilačko radno mesto se utvrđuje rešenjem u skladu sa pravilima opšteg upravnog postupka, gde se određuje platna grupa u kojoj se nalazi položaj odnosno izvršilačko radno mesto (kada je u pitanju izvršilačko radno mesto određuje se i platni razred).

Prema Zakonu o plati DSN, čl. 13, najveći koeficijent (u okviru prve platne grupe) iznosi 9,00 a najniži koeficijent (za prvi platni razred u okviru trinaeste platne grupe) iznosi 1,40 tj. odnos najvišeg i najnižeg koeficijenta iznosi 6,42:1 što znači da je najviša osnov- 
na plata državnog službenika na položaju prve platne grupe veća za 6,42 puta od najniže osnovne plate državnog službenika na izvršilačkom radnom mestu trinaeste platne grupe sa prvim platnim razredom.

Uzimajući u obzir raspon visine mesečne minimalne zarade (Zakon o radu, čl. 112) u 2016. godini ${ }^{1}$, najniža osnovna plata državnog službenika (izračunata po koeficijentu za trinaestu platnu grupu i prvi platni razred) iznosiće više od minimalne zarade, a u slučaju privremene sprečenosti za rad propisan je zaštitni institut u članu 33. stav 4. Zakona o plati DSN, prema kojem naknada plate za državnog službenika ne može biti niža od minimalne zarade utvrđene opštim propisima o radu.

Državni službenik može po osnovu dve uzastopne godišnje ocene da napreduje za jedan ili dva platna razreda.

Po pitanju državnih nameštenika, koeficijenti za radna mesta nameštenika nalaze se u rasponu do šest platnih grupa tj. od koeficijenta 1 šeste platne grupe do koeficijenta 2,53 prve platne grupe tako da platna grupa odgovara vrsti radnog mesta određenog sistematizacijom kod budžetskog korisnika. U ovom slučaju, najniža osnovna plata državnog nameštenika niža je od minimalne zarade u 2016. godini tako da, u situaciji kada je državnom namešteniku rešenjem određen koeficijent prema šestoj platnoj grupi, u istom rešenju je potrebno utvrditi i zaštitnu klauzulu, da se licu određuje minimalna zarada za standardni učinak i vreme u skladu sa opštim propisom o radu.

Zakonom o plati DSN u čl. 23 do 28. propisani su dodaci na platu, koji se obračunavaju po osnovu osnovne plate ili radnog sata osnovne plate, prema sledećem:

- dodatak na osnovnu platu od $0,4 \%$ osnovne plate za svaku navršenu godinu rada u radnom odnosu kod poslodavca (minuli rad),

- dodatak za rad noću u visini $26 \%$ vrednosti radnog sata osnovne plate državnog službenika, za rad noću od 22 sata do 6 sati narednog dana,

- dodatak za rad na dan praznika koji nije radni dan u visini $110 \%$ vrednosti radnog sata osnovne plate,

- dodatak za dodatno opterećenje od najmanje 10 radnih dana koji mesečno iznosi $4 \%$ osnovne plate, odnosno $5 \%$ osnovne plate ako državni službenik zamenjuje rukovodioca unutrašnje jedinice. Dodatak za dodatno opterećenje od najmanje 20 radnih dana mesečno iznosi $8 \%$ osnovne plate, odnosno 10\% osnovne plate ako državni službenik zamenjuje rukovodioca unutrašnje jedinice,

- dodatak za svaki sat prekovremenog rada koji nije kompenzovan preraspodelom radnog vremena, gde se pored $100 \%$ radnog sata osnovne plate preko punog radnog vremena plaća i $26 \%$ vrednosti radnog sata osnovne plate.

- dodatak za pripravnost u visini $10 \%$ vrednosti radnog sata osnovne plate za vreme pripravnosti

Zakonom o platama u članu 29. propisano je da državni službenik koji radi na položaju ima pravo samo na dodatak za vreme provedeno u radnom odnosu.

\footnotetext{
${ }^{1}$ Vlada Republike Srbije donela je Odluku o visini minimalne cene rada za period januar-decembar 2016. godine („Službeni glasnik RS“, br. 79/15) kojom je utvrđena minimalna cena rada, bez poreza i doprinosa za obavezno socijalno osiguranje, po radnom času za period januar-decembar 2016. godine u iznosu od 121 dinar (neto). Za mesec sa najmanjim brojem radnih dana (20 radnih dana) standardno po osam sati rada minimalna zarada iznosi $20 \times 8 \times 121=19.360$ dinara odnosno u mesecu sa najvećim brojem radnih dana visina minimalne zarade iznosi $23 \times 8 \times 121=22.264$ dinara.
} 
Različito od načina kako je opštom regulativom u sferi radnih odnosa uređeno materijalno pitanje odnosa između dodataka na platu, prema Zakonu o plati DSN, dodatak za prekovremeni rad isključuje ostale dodatke na platu (sem dodatka za minuli rad i pripravnost) pri čemu se ostali dodaci međusobno ne isključuju.

Nameštenik pod istim uslovima i na isti način ostvaruje pravo na dodatke, kao i državni službenik, osim prava na dodatak za dodatno opterećenje na radu.

lako je Zakonom o plati DSN u članu 48. regulisano da državni nameštenik ima pravo na dodatak za ostvarene rezultate rada jednom u tri meseca ako je u tom kvartalu postigao natprosečne rezultate, Zakonom o budžetu za 2016. godinu u članu 10. nisu planirana sredstva za ovu namenu.

\section{Obračun plate državnih službenika i nameštenika}

Da bi se adekvatno prikazala formula za obračun bruto plate preko neto osnovice potrebno je utvrditi preračun sa neto zarade na bruto zaradu, polazeći od propisa kojima je uređen porez na dohodak i doprinosi za obavezno socijalno osiguranje.

Zakonom o porezu na dohodak građana, u čl. 2, 15a i 16. propisano je da se bruto zarada za lice koje je radilo u mesecu puno radno vreme oporezuje po stopi od $10 \%$ uz poresku olakšicu koja trenutno iznosi 11.604 dinara.

Zakonom o doprinosima, u čl. 3, 7, 8, 9, 13. i 44. regulisano je da se iz mesečne bruto zarade zaposlenog obračunava (bez umanjenja) doprinos za penzijsko i invalidsko osiguranje po stopi $14 \%$, doprinos za zdravstveno osiguranje po stopi $5,15 \%$ i doprinos za nezaposlenost $0,75 \%$. Zbirna stopa doprinosa na teret zaposlenog iznosi 19,9\%. Na teret poslodavca obračunava se doprinos za penzijsko i invalidsko osiguranje po stopi $12 \%$, doprinos za zdravstveno osiguranje po stopi $5,15 \%$ i doprinos za nezaposlenost $0,75 \%$. Ukoliko zaposleni radi na radnom mestu gde se staž osiguranja računa sa uvećanim trajanjem, zaračunavaju se dodatni doprinosi na teret poslodavca u rasponu $3,7 \%$ $11 \%$ u zavisnosti od stepena uvećanja od 12/14 do 12/18.

Uz pretpostavku da je mesečna bruto zarada zaposlenog viša od najniže mesečne osnovice za plaćanje doprinosa, niža od najviše mesečne osnovice za plaćanje doprinosa, izvodi se sledeća formula za preračun bruto zarade iz neto zarade i obrnuto:

1) Bruto zarada $=$ Neto zarada + Porez + Doprinosi na teret zaposlenog;

2) Bruto zarada $=$ Neto zarada $+0,1 \times($ Bruto zarada -11.604$)+0,199 \times$ Bruto zarada;

3) Bruto zarada $=$ Neto zarada $+0,1 \times$ Bruto zarada $-1.160,4+0,199 \times$ Bruto zarada;

4) Bruto zarada $x(1-(0,1+0,199))=$ Neto zarada $-1.160,4$;

5) Bruto zarada $x(1-0,299)=$ Neto zarada $-1.160,4$;

6) Bruto zarada $\times 0,701=$ Neto zarada $-1.160,4$;

Formule za preračun bruto ili neto zarade

Bruto zarada $=($ Neto zarada $-1.160,4) / 0,701$ ili Neto zarada $=$ Bruto zarada $x$ $0,701+1.160,4$

$\mathrm{Na}$ osnovu izvedene jednakosti, formula za obračun bruto plate po osnovu neto osnovice izgledala bi: 


$$
B P=\frac{(N o x K f+N D)-1.160,4}{0,701}
$$

$\mathrm{BP}$ - Bruto plata - plata državnog službenika ili nameštenika u bruto iznosu,

No - Neto osnovica - osnovica za obračun plate državnih službenika i nameštenika u neto iznosu,

$\mathrm{Kf}$ - koeficijent - koeficijent prema platnom razredu i/ili platnoj grupi za državnog službenika ili nameštenika,

ND - Neto dodaci - dodaci na platu državnog službenika ili nameštenika u neto iznosu.

U nastavku utvrđivanja jedinstvene bruto osnovice za obračun plate državnih službenika i nameštenika, poći se od sledećeg primera:

\section{Primer obračuna plate državnih službenika i nameštenika}

Radi ilustracije, pretpostaviće se, da je državnom službeniku u zvanju savetnik rešenjem nadležnog organa utvrđen koeficijent za radno mesto u visini 3,39 (osma platna grupa i sedmi platni razred), da lice ima navršenih deset godina u radnom odnosu kod trenutnog poslodavca, da po osnovu posebnog rešenja zamenjuje rukovodioca unutrašnje jedinice i prima dodatak za dodatno opterećenje u visini $10 \%$ osnovne plate, da je radilo puno radno vreme 176 sati u posmatranom mesecu i pri tom još ostvarilo osam sati rada u dane praznika koji nisu radni dani (nije odsustvovalo sa posla za dan praznika koji nije radni dan), za šta mu je posebnim rešenjem priznato pravo na dodatak za rad na dan praznika koji nije radni dan, u visini $110 \%$ radnog sata plate za svaki sat prazničnog rada. Mesečna bruto plata lica nalazi se između najniže mesečne osnovice za plaćanje doprinosa i najviše mesečne osnovice za plaćanje doprinosa.

Tabela 2 - Obračun neto i bruto plate za državnog službenika

\begin{tabular}{|c|l|r|}
\hline R. br. & \multicolumn{1}{|c|}{ Naziv } & \multicolumn{1}{|c|}{ Iznos } \\
\hline 1 & Neto osnovica & $17.101,29$ \\
\hline 2 & Koeficijent za VIII platnu grupu i 7 platni razred & 3,39 \\
\hline 3 & Neto osnovna plata (red. br. 1 x red. br. 2) & $57.973,37$ \\
\hline 4 & Fond radnih sati u mesecu & 176 \\
\hline 5 & Radni sat neto osnovne plate (red. br. 3 / red. br. 4) & 329,39 \\
\hline 5.1 & Ostvareni sati rada & 176 \\
\hline $\mathbf{5 . 2}$ & Neto osnovna plata za ostvarene sate rada (red. br. 5.1 x red. br. 5) & $\mathbf{5 7 . 9 7 3 , 3 7}$ \\
\hline 6 & Neto dodatak za dodatno opterećenje 10\% neto osnovne plate (red. br. 3 x 10\%) & $5.797,34$ \\
\hline 7 & Dodatak za praznični rad 110\% radnog sata osnovne plate (red. br. 5 x 110\%) & 362,33 \\
\hline 8 & Broj sati rada u dane praznika koji nisu radni dani & 8 \\
\hline 9 & Neto dodatak za rad u dane praznike koji nisu radni dani (red. br. 7 x red. br. 8) & $2.898,67$ \\
\hline 10 & $\begin{array}{l}\text { Neto dodatak za minuli rad 4\% radnog sata plate za ostvarene sate rada } \\
\text { (red. br. 5.1 x red. br. 5 x 4\%) }\end{array}$ & $2.318,93$ \\
\hline 11 & Neto plata (red. br. 5.2 + red. br. 6 + red. br. 9 + red. br. 10) & $\mathbf{6 8 . 9 8 8 , 3 1}$ \\
\hline 12 & Bruto plata (red. br. 11 - 1,160,4)/0,701 & $\mathbf{9 6 . 7 5 8 , 7 9}$ \\
\hline 13 & Bruto dodatak za dodatno opterećenje (red. br. 6 / 0,701) & $8.270,10$ \\
\hline 14 & Bruto dodatak za rad u dane praznike koji nisu radni dani (Red. br. 9 / 0,701) & $4.135,05$ \\
\hline 15 & Bruto dodatak za minuli rad 4\% osnovne plate (Red. br. 10 / 0,701) & $3.308,04$ \\
\hline 16 & Bruto osnovna plata (Red. br. 12 - Red. br. 13 - Red. br. 14 - Red. br. 15) & $\mathbf{8 1 . 0 4 5 , 6 1}$ \\
\hline
\end{tabular}


Polazeći od stava da je bruto plata zbir bruto osnovne plate i bruto dodataka na platu, da je bruto osnovna plata proizvod bruto osnovice za platu i koeficijenta za radno mesto i da je bruto dodatak u stvari neto dodatak uvećan za poreze i doprinose na teret zaposlenog bez poreske olakšice može se prikazati sledeća jednakost:

1) $\mathrm{BP}=\mathrm{BoP}+\mathrm{BD}=\frac{(\mathrm{No} \times \mathrm{Kf}+\mathrm{ND})-1.160,4}{0,701}$

BP - Bruto plata - plata državnog službenika ili nameštenika u bruto iznosu,

BoP - Bruto osnovna plata - osnovna državnih službenika ili nameštenika u bruto iznosu, nosu,

ND - Neto dodaci - dodaci na platu državnog službenika ili nameštenika u bruto iz-

No - Neto osnovica - osnovica za obračun plate državnih službenika i nameštenika u neto iznosu,

$\mathrm{Kf}$ - koeficijent - koeficijent prema platnom razredu i/ili platnoj grupi za državnog službenika ili nameštenika,

ND - Neto dodaci - dodaci na platu državnog službenika ili nameštenika u neto iznosu

Bo - Bruto osnovica - osnovica za obračun plate državnih službenika i nameštenika u neto iznosu

2) $B 0 x \mathrm{Kf}+\mathrm{BD}=\frac{(\text { No } x \mathrm{Kf}+\mathrm{ND})-1.160,4}{0,701}$

3) $B o x K f+B D=\frac{\text { No } x \mathrm{Kf}-1.160,4}{0,701}+\frac{\mathrm{ND}}{0,701}$ kako je $\mathrm{BD}=\frac{\mathrm{ND}}{0,701}$

4) $B o=\frac{\text { No } x \mathrm{Kf}-1.160,4}{\mathrm{Kf} \times 0,701}$

Po izvedenoj formuli a prema zadatim vrednostima u primeru, bruto osnovica iznosila bi $\frac{17.101,29 \times 3,39-1.160,4}{3,39 \times 0,701}=23.907,26$ i po istoj bi se dobila bruto osnovna plata $23.907,26 \times 3,39=81.045,61$, što zadovaljava $\mathrm{i}$ jednakost $\mathrm{BoP}=$ $\frac{\text { NoP }-1.160,4}{0,701}$ tj. $\frac{17.101,29 \times 3,39-1.160,4}{0,701}=81.045,61$.

Međutim, bruto dodaci po osnovu dodatnog opterećenja, prazničnog rada i minulog rada ranije izvedeni iz neto dodataka u gornjem primeru se ne mogu dobiti iz kalkulisane bruto osnovne plate: 
Vojnoekonomski pregled

\begin{tabular}{|c|l|r|}
\hline R. br. & \multicolumn{1}{|c|}{ Naziv } & \multicolumn{1}{|c|}{ Iznos } \\
\hline 1 & Bruto osnovica & $23.907,26$ \\
\hline 2 & Koeficijent za VIII platnu grupu i 7 platni razred & 3,39 \\
\hline 3 & Bruto osnovna plata (red. br. 1 x red. br. 2) & $\mathbf{8 1 . 0 4 5 , 6 1}$ \\
\hline 4 & Fond radnih sati u mesecu & 176 \\
\hline 5 & Radni sat bruto osnovne plate (red. br. 3 / red. br. 4) & 460,49 \\
\hline 6 & Bruto dodatak za dodatno opterećenje 10\% bruto osnovne plate (red. br. 3 x 10\%) & $\mathbf{8 . 1 0 4 , 5 6}$ \\
\hline 7 & Iznos 110\% radnog sata bruto osnovne plate (red. br. 5 x 110\%) & 506,54 \\
\hline 8 & Broj sati rada u dane praznika koji isu radni dani & 8 \\
\hline 9 & Bruto dodatak za rad u dane praznike koji nisu radni dani (Red. br. 7 x Red. br. 8) & $\mathbf{4 . 0 5 2 , 2 8}$ \\
\hline 10 & Bruto dodatak za minuli rad 4\% osnovne plate (Red. br. 3 x 4\%) & $\mathbf{3 . 2 4 1 , 8 2}$ \\
\hline
\end{tabular}

Zbog toga, dobijena bruto osnovica se ne može jedinstveno koristiti. S obzirom da se pojedini dodaci na platu određuju po radnom satu osnovne plate bez linearne zavisnosti na ukupno ostvarenu platu, da se poresko rasterećenje računa srazmerno broju ostvarenih sati u odnosu na utvrđeno radno vreme zaposlenog a na šta ne utiče ostvareni iznos plate i zbog toga što se porezi i doprinosi plaćaju na bruto iznos dodataka na platu bez poreske olakšice, bruto osnovica za utvrđivanje bruto dodataka na platu razlikuje se od bruto osnovice za utvrđivanje bruto osnovne plate. Ako se pođe od tzv. „brutiranog“ iznosa propisane neto osnovice - 17.101,29 / 0,701 $=24.395,56$ pa se izvrši korekcija bruto osnovne plate za bruto korektivni faktor tj. 1.160,4 / 0,701 = 1.655,35 moglo bi se doći do pravilnih iznosa i bruto osnovne plate i bruto dodataka na platu:

Tabela 3 - Obračun bruto osnovne plate i bruto dodataka na platu i preračun na neto platu i dodatke

\begin{tabular}{|c|l|r|}
\hline R. br. & \multicolumn{1}{|c|}{ Naziv } & \multicolumn{1}{|c|}{ Iznos } \\
\hline 1 & Brutirani iznos neto osnovice (17.101,29 / 0,701) & $24.395,56$ \\
\hline 2 & Koeficijent za VIII platnu grupu i 7 platni razred & 3,39 \\
\hline 3 & Bruto osnovna plata (red. br. 1 x red. br. 2 - (1.160,4 / 0,701)) & $81.045,61$ \\
\hline 4 & Fond radnih sati u mesecu & 176 \\
\hline 5 & Bruto radni sat osnovne plate (red. br. 1 x red. br. 2 / red. br. 4) & 469,89 \\
\hline 6 & Bruto dodatak za dodatno opterećenje 10\% (red. br. 1 x red. br. 2 x 10\%) & $8.270,10$ \\
\hline 7 & $110 \%$ radnog sata "brutirane" neto osnovne plate (red. br. 5 x 110\%) & 516,88 \\
\hline 8 & Broj sati rada u dane praznika koji nisu radni dani & 8 \\
\hline 9 & Bruto dodatak za rad u dane praznike koji nisu radni dani (red. br. 7 x red. br. 8) & $4.135,05$ \\
\hline 10 & Bruto dodatak za minuli rad 4\% osnovne plate (red. br. 1 x red. br. 2 x 4\%) & $3.308,04$ \\
\hline 11 & Bruto plata (red. br. 3 + red. br. 6 + red. br. 9 + red. br. 10) & $\mathbf{9 6 . 7 5 8 , 7 9}$ \\
\hline 12 & Neto plata (red. br. 11 x 0,701 + 1.160,4) & $\mathbf{6 8 . 9 8 8 , 3 1}$ \\
\hline 13 & Neto dodatak za dodatno opterećenje (red. br. 6 x 0,701) & $5.797,34$ \\
\hline 14 & Neto dodatak za rad u dane praznike koji nisu radni dani (red. br. 9 x 0,701) & $2.898,67$ \\
\hline 15 & Neto dodatak za minuli rad 4\% osnovne plate (red. br. 10 x 0,701) & $2.318,93$ \\
\hline 16 & Neto osnovna plata (red. br. 12 - red. br. 13 - red. br. 14 - red. br. 15) & $\mathbf{5 7 . 9 7 3 , 3 7}$ \\
\hline
\end{tabular}




\section{Obračun plate profesionalnih pripadnika Vojske}

\section{Elementi plate profesionalnog pripadnika VS}

Zakonom o Vojsci Srbije, u čl. 81. do 95. opšte su određeni uslovi, merila i način obračuna plate i drugih novčanih primanja profesionalnih pripadnika Vojske Srbije (u daljem tekstu: VS), dok je na osnovu člana 95. stav 3. Zakona o VS, Vlada donela Pravilnik o platama profesionalnih pripadnika Vojske Srbije (u daljem tekstu: Pravilnik) kojim su bliže uređena materijalna rešenja po pitanju obračuna plate i određenih novčanih primanja za profesionalne pripadnike VS. U profesionalne pripadnike VS svrstavaju se profesionalna vojna lica (u daljem tekstu: PVL) i civilna lica na službi u VS (u daljem tekstu: CL). PVL čine oficiri, podoficiri i profesionalni vojnici (skr.: OF, POF i PV). CL čine vojni službenici i nameštenici (u daljem tekstu: VSiN).

Mesečna plata profesionalnog pripadnika VS dobija se kao proizvod koeficijenta za platu i osnovice za obračun plate profesionalnih pripadnika VS. Osnovica se utvrđuje zaključkom Vlade u bruto iznosu (sa porezom i doprinosima na teret zaposlenog), tako da proizvod koeficijenta i osnovice označava bruto platu profesionalnog pripadnika VS (neto, porez i doprinosi na teret zaposlenog). Neto plata se dobija po odbitku poreza i doprinosa od bruto plate. Plata se uvećava dodacima na platu, koji se utvrđuju po osnovu plate, u bruto iznosu.

\section{Koeficijent plate za profesionalno vojno lice}

Koeficijent za platu PVL sastoji se od osnovnog i dodatnog koeficijenta. Za OF i POF osnovni koeficijent sastoji se od koeficijenta prema činu i koeficijenta prema položajnoj grupi, a za PV od koeficijenta prema činu i dužnosti. Koeficijent prema činu za OF i POF razvrstan je u rasponu 0,28 - 1,40, koeficijent prema položaju razvrstan je za 23 položajne grupe u opsegu 0,61 - 2,50, a koeficijent prema činu i dužnosti za PV kreće se od 0,87 do 0,94 . Najveću vrednost u osnovnom koeficijentu za OF i POF ima koeficijent prema položajnoj grupi, odnosno najveće razlike zastupljene se između vrednosti koeficijenta niže i više položajne grupe, što proizilazi iz težnje da se na adekvatan način vrednuje odgovornost koju povlači svaka položajna grupa u Vojsci. Odnos najvišeg osnovnog koeficijenta $(1,40+2,50)$ i najnižeg $(0,87)$ ekvivalentan je razmeri $4,48: 1$ što pokazuje manje odstupanje najviše i najniže plate, za razliku od koeficijenata plate za državne službenike i nameštenike $(6,42: 1)$.

Dodatni koeficijent za platu za PVL sastoji od koeficijenta za posebne uslove službe, koeficijenta zbog težine, karaktera i službe u određenoj jedinici (ili ustanovi) i koeficijenta za specifičnu vojnu službu. Koeficijent za posebne uslove službe za PV, OF i POF u radnom odnosu na određeno iznosi $20 \%$ osnovnog koeficijenta, a za OF i POF u radnom odnosu na neodređeno $25 \%$ osnovnog koeficijenta. Razlika se ogleda u tome, što pored ostalih okolnosti pod kojima vrše službu u Vojsci, OF i POF koji stupaju u službu na neodređeno vreme nemaju mogućnost izbora mesta službovanja, za razliku od PV, OF i POF koji ugovorno zasnivaju radni odnos u VS. Koeficijent zbog težine, karaktera i trajanja rada u određenoj jedinici - usta- 
novi, određen je u procentu u rasponu 10\%-25\% osnovnog koefcijenta, odnosno u nominalnoj vrednosti od 0,108 do 0,300. Koeficijent za specifičnu vojnu službu razlikuje se prema letačkoj službi, padobranskoj službi, ronilačkoj službi i službi uništavanja neeksplodiranih ubojnih sredstava (UbS). Koeficijent za letačku službu deli se prema kategoriji letača (pilot ili ostalo letačko osoblje), kategoriji vazduhoplova, stručnoj i borbenoj osposobljenosti i određen je u vrednosti od 0,19 do 1,06 sa uvećanjem u procentu po osnovu letačkog zvanja od $20 \%$ do $35 \%$ i godina provedenih u letačkoj službi, od 3\% do $15 \%$. Koeficijent za letačku službu ne može biti veći od 2,38. Koeficijent za padobransku službu prema padobranskom zvanju kreće se od 0,10 do 0,50 s tim da se uvećava za godine provedene u padobranskoj službi od $3 \%$ do $15 \%$. Koeficijent za ronilačku službu iznosi $20 \%$ osnovnog koeficijenta. Koeficijent za službu uništavanja neeksplodiranih UbS iznosi $10 \%$ osnovnog koeficijenta.

\section{Koeficijent plate za civilno lice na službi u Vojsci Srbije}

Utvrđivanje plate za civilno lice na službi u VS počinje od koeficijenta za radno mesto koje se zavisno od složenosti i odgovornosti poslova, potrebnih znanja, sposobnosti i uslova za rad svrstava u 14 platnih grupa sa 9 platnih razreda, u vrednosti od 0,559 do 2,715 (4,85:1). Lice može po osnovu dve uzastopne godišnje ocene napredovati za jedan ili dva platna razreda do najviše devet platnih razreda ili po osnovu godišnje nepovoljne ocene da umanji koeficijent za jedan platni razred. Ovako utvrđen koeficijent se uvećava za $20 \%$, po osnovu posebnih uslova službe u VS. Za manji broj civilnih lica koja službu vrše u određenim jedinicama - ustanovama, koeficijent za radno mesto se uvećava za $10 \%$. Civilno lice za obavljanje specifične vojne službe ostvaruje koeficijent za specifičnu vojnu službu pod istim uslovima i merilima kao profesionalna vojna lica.

\section{Dodaci na platu profesionalnih pripadnika VS}

Profesionalnim pripadnicima VS pod određenim uslovima pripadaju dodaci na platu (Pravilnik, čl. 30. do 37):

- za svaku navršenu godinu u radnom odnosu, u visini 0,4\% pripadajuće plate,

- dodatak za rad noću od 22 do 06 časova, u visini $26 \%$ plate,

- dodatak za rad na dan praznika koji nije radni dan, u visini $110 \%$ radnog sata plate,

- dodatak za dodatno opterećenje, u visini 10\% plate,

- dodatak za prekovremeni rad koji nije kompenzovan slobodnim satima, u visini $26 \%$ radnog sata plate (Kada se plaća sat rada preko punog radnog vremena, pored dodatka $26 \%$ radnog sata plate plaća se i još $100 \%$ radnog sata plate ),

- paušal u visni $60 \%$ ili $70 \%$ plate za puno radno vreme, za profesionalnog pripadnika iz bataljona vojne policije za specijalne namene „Kobre“ za dane angažovanja na neposrednom obezbeđenju lica ili objekata,

- dodatak za pripravnost u visini $10 \%$ radnog sata plate, za potrebe kriptozaštite podataka.

Poredeći sa platama ostalih budžetskih korisnika, plata profesionalnih pripadnika VS sastoji se od najvećeg broja varijabilnih komponenata za obračun. Uzrok se ogleda u činjenici da poslovi odbrane obuhvataju širok spektar raznovrsnih aktivnosti sa različitim stepenom rizika, koje se nisu mogle jedinstveno vrednovati. 
Tabela 4 - Prikaz elemenata plate profesionalnih pripadnika VS

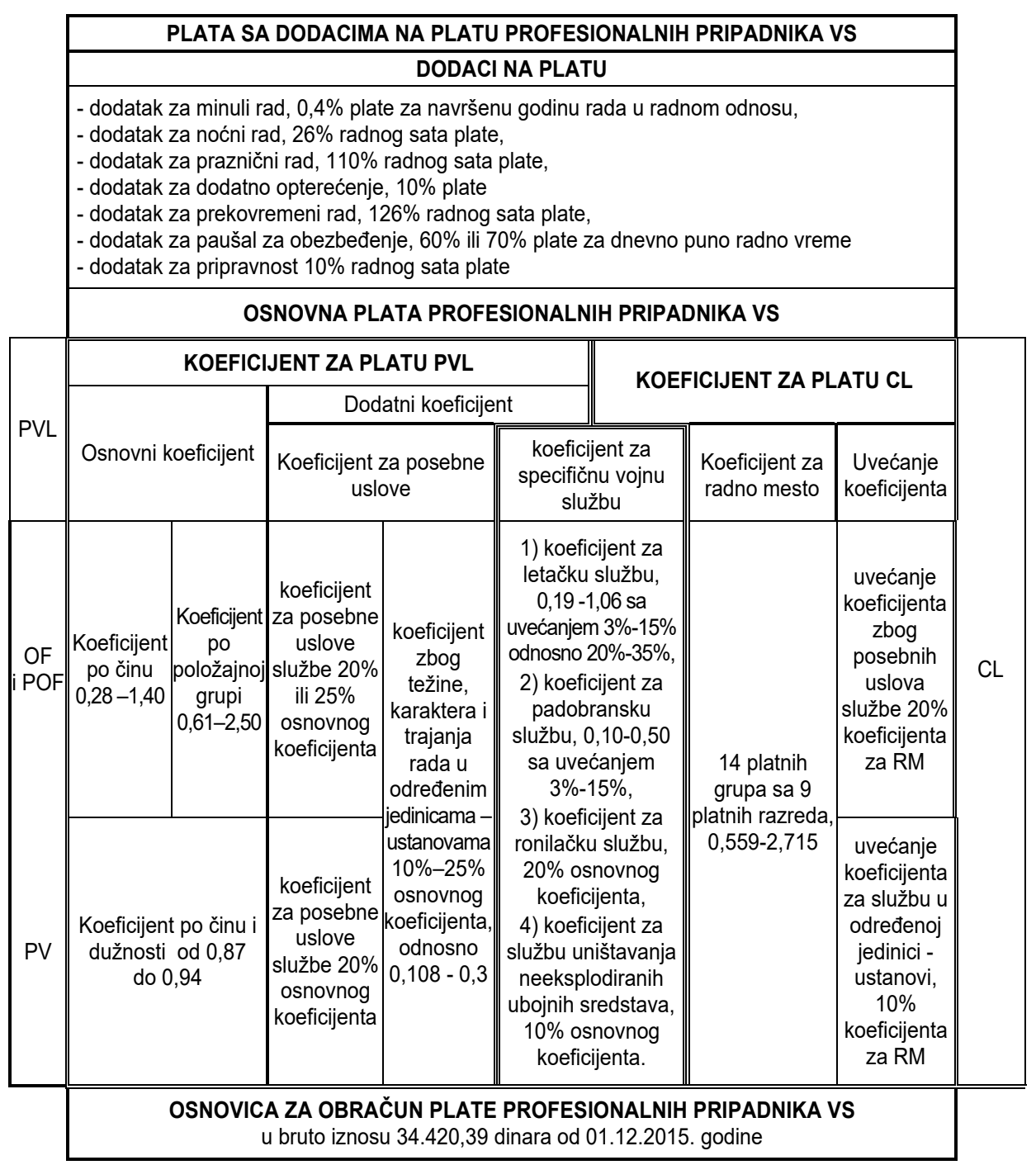

\section{Primer obračuna plate za PVL}

U primeru će se prikazati mesečni obračun plate za puno radno vreme za oficira $u$ radnom odnosu u činu potpukovnika, koji službu vrši u jedinici ranga brigade, koji ima navršenih 20 godina rada u radnom odnosu, koji obavlja letačku službu 15 godina i trenutno na vazduhoplovu prve kategorije sa petom kategorijom borbene i stručne osposobljenosti, koji je u mesecu radio 40 sati noću i osam sati na dan praznika koji nije radni dan. 
Tabela 5 - Primer obračuna plate za PVL

\begin{tabular}{|c|c|c|c|}
\hline R. br. & Naziv & koeficijent & $\begin{array}{l}\text { Iznos } \\
\text { (koeficijent } x \\
\text { osnovica) }\end{array}$ \\
\hline 1 & \multicolumn{2}{|l|}{ Osnovica za obračun plate u bruto iznosu } & $34.420,39$ \\
\hline 2 & čin potpukovnika & 0,72 & $24.782,68$ \\
\hline 3 & osma položajna grupa & 1,75 & $60.235,68$ \\
\hline 4 & $\begin{array}{l}\text { koeficijent za posebne uslove službe } \\
25 \% \text { osnovnog koeficijenta (red. br. } 2+\text { red. br. } 3 \text { ) } \times 0,25\end{array}$ & 0,6175 & $21.254,59$ \\
\hline 5 & koeficijent za službu u brigadi & 0,108 & $3.717,40$ \\
\hline 6 & koeficijent za letačku službu sa uvećanjem $15 \%(1,06$ x 1,15) & 1,219 & $41.958,46$ \\
\hline 7 & $\begin{array}{l}\text { koeficijent plate } \\
\text { (red. br. } 2+\text { red. br. } 3+\text { red. br. } 4+\text { red. br. } 5+\text { red. br. } 6 \text { ) }\end{array}$ & 4,4145 & $151.948,81$ \\
\hline 8 & Mesečni fond sati & \multicolumn{2}{|c|}{176} \\
\hline 9 & Radni sat plate (red. br. 7 / red. br. 8) & 0,025082386 & 863,35 \\
\hline 10 & $\begin{array}{l}\text { Ostvareni časovi rada } \\
\text { (u primeru je lice radilo puno radno vreme) }\end{array}$ & \multicolumn{2}{|c|}{176} \\
\hline 11 & $\begin{array}{l}\text { Bruto plata za ostvarene časove rada } \\
\text { (red. br. } 9 \times \text { red. br. 10) }\end{array}$ & 4,4145 & $151.948,81$ \\
\hline 12 & dodatak za minuli rad $(0,08 \times$ red. br. $9 \times$ red. br. 10$)$ & 0,35316 & $12.155,90$ \\
\hline 13 & dodatak za rad noću (40 sati x 0,26 x red. br. 9) & 0,260856818 & $8.978,79$ \\
\hline 14 & dodatak za praznični rad (osam sati x $110 \%$ x red. br. 9) & 0,220725 & $7.597,44$ \\
\hline 15 & $\begin{array}{l}\text { Bruto plata sa dodacima } \\
\text { (red. br. } 11+\text { red. br. } 8+\text { red. br. } 9+\text { red. br. } 10)\end{array}$ & 5,249241818 & $180.680,95$ \\
\hline 16 & poreska olakšica za puno radno vreme & & 11.604 \\
\hline 17 & $\begin{array}{l}\text { Osnovica za oporezivanje uz poresko umanjenje } \\
\text { (red. br. } 15 \text { - 11.604) }\end{array}$ & & $169.076,95$ \\
\hline 18 & Porez $10 \%$ (red. br. $17 \times 10 \%$ ) & & $16.907,70$ \\
\hline 19 & $\begin{array}{l}\text { Osnovica za doprinose } \\
\text { (bruto plata se nalazi između najniže i najviše osnovice za plaćanje } \\
\text { doprinosa) }\end{array}$ & & $180.680,95$ \\
\hline 20 & Doprinos za PIO na teret zaposlenog $14 \%$ (red. br. $19 \times 14 \%$ ) & & $25.295,33$ \\
\hline 21 & Doprinos za zdravstvo 5,15\% (red. br. $19 \times 5,15 \%$ ) & & $9.305,07$ \\
\hline 22 & Doprinos za nezaposlenost $0,75 \%$ (red. br. $19 \times 0,75 \%$ ) & & $1.355,11$ \\
\hline 23 & $\begin{array}{l}\text { Neto plata sa dodacima } \\
\text { (red. br. } 15 \text { - red. br. } 18 \text { - red. br. } 20 \text { - red. br. } 21 \text { - red. br. 22) ili } \\
\text { (red. br. } 15 \text { x } 0,701+1.160,4)\end{array}$ & & $127.817,75$ \\
\hline
\end{tabular}




\section{Primer obračuna plate za $\mathrm{CL}$}

Civilno lice je postavljeno na radno mesto u okviru treće platne grupe i trećeg platnog razred sa brojem bodova 834 , s tim da je po osnovu dve uzastopne godišnje ocene napredovalo za dva platna razreda, zbog čega mu je rešenjem određen koeficijent za radno mesto 1,676 (peti platni razred). Ima navršenih 20 godina rada u radnom odnosu. Fond sati za puno radno vreme u mesecu je 184. Postoje dva dana praznika koji nisu radni dani, pri čemu je lice po nalogu poslodavca radilo osam sati na jedan dan praznika koji nije radni dan. Lice je radilo 176 sati a osam sati je odsustvovalo na dan praznika.

Tabela 6 - Primer obračuna plate za $C L$

\begin{tabular}{|c|c|c|c|}
\hline R. br. & Naziv & koeficijent & $\begin{array}{c}\text { Iznos } \\
\text { (koeficijent x } \\
\text { osnovica) }\end{array}$ \\
\hline 1 & \multicolumn{2}{|l|}{ Osnovica za obračun plate u bruto iznosu } & $34.420,39$ \\
\hline 2 & Koeficijent za III platnu grupu 5 platni razred & 1,676 & $57.688,57$ \\
\hline 3 & \begin{tabular}{|l|} 
Uvećanje koeficijenta za radno mesto za posebne uslove \\
službe 0,20 x osnovni koeficijent odnosno (red. br. 2 × 0,20)
\end{tabular} & 0,3352 & $11.537,71$ \\
\hline 4 & koeficijent plate CL (red. br. 2 + red. br. 3) & 2,0112 & $69.226,29$ \\
\hline 5 & Mesečni fond sati & \multicolumn{2}{|c|}{184} \\
\hline 6 & Radni sat plate (red. br. 4 / red. br. 5) & 0,010930435 & 376,23 \\
\hline 7 & $\begin{array}{l}\text { Ostvareni časovi rada } \\
\text { (u primeru je lice radilo puno radno vreme) }\end{array}$ & \multicolumn{2}{|c|}{176} \\
\hline 8 & Časovi odsustva za državni praznik & \multicolumn{2}{|c|}{8} \\
\hline 9 & Bruto plata za ostvarene časove rada (red. br. 7 x red. br. 6) & 1,923756522 & $66.216,45$ \\
\hline 10 & $\begin{array}{l}\text { Bruto naknada plate za odsustvo za dan državnog } \\
\text { praznika (red. br. } 8 \text { x red. br. 6) }\end{array}$ & 0,087443478 & $3.009,84$ \\
\hline 11 & $\begin{array}{l}\text { dodatak za minuli rad } 20 \text { godina } \times 0,4 \%=8 \% \\
(0,08 \times \text { (red. br. } 7+\text { red. br. } 8) \times \text { red. br. } 6)\end{array}$ & 0,160896 & $5.538,10$ \\
\hline 12 & dodatak za praznični rad (osam sati x $110 \%$ x red. br. 6) & 0,096187826 & $3.310,82$ \\
\hline 13 & $\begin{array}{l}\text { Bruto plata sa naknadom plate i dodacima } \\
\text { (red. br. } 9 \text { + red. br. } 10 \text { + red. br. } 11 \text { + red. br. 12) }\end{array}$ & 2,268283826 & $78.075,21$ \\
\hline \multicolumn{4}{|c|}{ Obračun neto plate sa naknadom plate i dodacima na platu } \\
\hline 14 & poreska olakšica za puno radno vreme & & 11.604 \\
\hline 15 & $\begin{array}{l}\text { Osnovica za oporezivanje uz poresko umanjenje } \\
\text { (red. br. } 13-11.604 \text { ) }\end{array}$ & & $66.471,21$ \\
\hline 16 & Porez $10 \%$ (red. br. $15 \times 10 \%$ ) & & $6.647,12$ \\
\hline 17 & $\begin{array}{l}\text { Osnovica za doprinose (red. br. 13) } \\
\text { (bruto plata se nalazi između najniže } \\
\text { i najviše osnovice za plaćanje doprinosa) }\end{array}$ & & $78.075,21$ \\
\hline 18 & Doprinos za PIO na teret zaposlenog 14\% (red. br. 17 x 14\%) & & $10.930,53$ \\
\hline 19 & Doprinos za zdravstvo 5,15\% (red. br. 17 x 5,15\%) & & $4.020,87$ \\
\hline 20 & Doprinos za nezaposlenost $0,75 \%$ (red. br. 17 × 0,75\%) & & 585,56 \\
\hline 21 & $\begin{array}{l}\text { Neto plata sa naknadom plate i dodacima } \\
\text { (red. br. } 13 \text { - red. br. } 16 \text { - red. br. } 18 \text { - red. br. } 19 \text { - red. } \\
\text { br. 20) ili (red. br. } 13 \text { x } 0,701+1.160,4 \text { ) }\end{array}$ & & $55.891,12$ \\
\hline
\end{tabular}




\section{Trošak poreza i doprinosa na platu izvedenu po neto odnosno bruto osnovici}

Radi analize poreskog uticaja, razmatraće se uporedne tabele obračuna osnovne plate po neto odnosno bruto osnovici, sa bruto platom koja sadrži neto platu, porez i doprinose na teret zaposlenog. Promene stopa doprinosa na teret poslodavca direktno utiču na rast ili pad ukupnog troška plate nezavisno od metode obračuna plate tako da nije potrebno posebno pratiti promene ove kategorije doprinosa (obzirom da je učinak na trošak doprinosa na teret poslodavca srazmeran promeni).

U prvoj tabeli, poći će se od metode obračuna plate po neto osnovici, na osnovu koje će se odrediti početni iznos neto odnosno bruto plate, dok će se u drugoj tabeli poći od bruto osnovice, koja će se odrediti u iznosu koji će dovesti do bruto odnosno neto plate u istom iznosu kao u slučaju obračuna po neto osnovici. Neto odnosno bruto osnovica se neće menjati kroz primere, radi usmeravanja pažnje na posledice promena stopa poreza i doprinosa na teret zaposlenog, koje su predmet analize.

Tabela 7 - Obračun plate po neto osnovici bez poreske olakšice

\begin{tabular}{|c|c|c|}
\hline R. br. & Naziv & Iznos \\
\hline 1 & Neto osnovica & $17.101,29$ \\
\hline 2 & Koeficijent & 5,57 \\
\hline 3 & Poreska olakšica & 0,00 \\
\hline 4 & Stopa poreza na dohodak & $10,00 \%$ \\
\hline 5 & Stopa doprinosa za PIO na teret zaposlenog & $14,00 \%$ \\
\hline 6 & Stopa doprinosa za zdr. osig. na teret zaposlenog & $5,15 \%$ \\
\hline 7 & Stopa doprinosa za osig. za sl. nez. na teret zaposlenog & $0,75 \%$ \\
\hline 8 & $\begin{array}{l}\text { Koeficijent za preračun } \\
1 \text { - (red. br. } 4 .+ \text { red. br. } 5 .+ \text { red. br. } 6+\text { red. br. } 7 \text { ) } \\
\end{array}$ & 0,701 \\
\hline 9 & Neto plata (red. br. $1 \mathrm{x}$ red. br. 2) & $95.254,19$ \\
\hline 10 & Bruto plata ((red. br. 9 - red. br. $3 \times$ red. br. 4) / red. br. 8) & $135.883,29$ \\
\hline 11 & Porez (red. br. 10 - red. br. 3) x (red. br. 4.) & $13.588,33$ \\
\hline 12 & Doprinos za PIO na teret zaposlenog (red. br. 5 x red. br. 10) & $19.023,66$ \\
\hline 13 & Doprinos za zdr. osig. na teret zaposlenog (red. br. 6 x red. br. 10) & $6.997,99$ \\
\hline 14 & Doprinos za osig. za sl. nez. na teret zaposlenog (red. br. 7 x red. br. 10) & $1.019,12$ \\
\hline
\end{tabular}


Tabela 8 - Obračun plate po bruto osnovici bez poreske olakšice

\begin{tabular}{|c|l|r|}
\hline R. br. & \multicolumn{1}{|c|}{ Naziv } & \multicolumn{1}{|c|}{ Iznos } \\
\hline 1 & Bruto osnovica & $\mathbf{2 4 . 3 9 5 , 5 6}$ \\
\hline 2 & Koeficijent & 5,57 \\
\hline 3 & Poreska olakšica & 0,00 \\
\hline 4 & Stopa poreza na dohodak & $10,00 \%$ \\
\hline 5 & Stopa doprinosa za PIO na teret zaposlenog & $14,00 \%$ \\
\hline 6 & Stopa doprinosa za zdr. osig. na teret zaposlenog & $5,15 \%$ \\
\hline 7 & Stopa doprinosa za osig. za sl. nez. na teret zaposlenog & $0,75 \%$ \\
\hline 8 & Koeficijent za preračun 1 - (red. br. 4. + red. br. 5. + red. br. 6 + red. br. 7) & 0,701 \\
\hline $\mathbf{9}$ & Bruto plata (red. br. 1 x red. br. 2) & $\mathbf{1 3 5 . 8 8 3 , 2 9}$ \\
\hline 10 & Neto plata (red. br. 9 x red. br. 8 + red. br. 3 x red. br. 4) & $\mathbf{9 5 . 2 5 4 , 1 9}$ \\
\hline 11 & Porez (red. br. 9 - red. br. 3) x (red. br. 4.) & $13.588,33$ \\
\hline 12 & Doprinos za PIO na teret zaposlenog (red. br. 5 x red. br. 9) & $19.023,66$ \\
\hline 13 & Doprinos za zdr. osig. na teret zaposlenog (red. br. 6 x red. br. 9) & $6.997,99$ \\
\hline 14 & Doprinos za osig. za sl. nez. na teret zaposlenog (red. br. 7 x red. br. 9) & $1.019,12$ \\
\hline
\end{tabular}

Prve dve tabele poslužiće kao bazni primeri po kojima će se upoređivati ishodi promena u narednim tabelama, usled promene stopa doprinosa i poreza. U nastavku, prvo će se razmatrati promene stope komponente doprinosa.

\section{Uticaj promene stope doprinosa na teret zaposlenog}

Tabela 9 - Obračun plate po neto osnovici bez poreske olakšice, sa uvećanom stopom doprinosa za penzijsko i invalidsko osiguranje na teret zaposlenog

\begin{tabular}{|c|l|r|}
\hline R. br. & \multicolumn{1}{|c|}{ Naziv } & \multicolumn{1}{|c|}{ Iznos } \\
\hline 1 & Neto osnovica & $\mathbf{1 7 . 1 0 1 , 2 9}$ \\
\hline 2 & Koeficijent & 5,57 \\
\hline 3 & Poreska olakšica & 0,00 \\
\hline 4 & Stopa poreza na dohodak & $10,00 \%$ \\
\hline $\mathbf{5}$ & Stopa doprinosa za PIO na teret zaposlenog & $\mathbf{1 5 , 0 0 \%} \uparrow$ \\
\hline 6 & Stopa doprinosa za zdr. osig. na teret zaposlenog & $5,15 \%$ \\
\hline 7 & Stopa doprinosa za osig. za sl. nez. na teret zaposlenog & $0,75 \%$ \\
\hline 8 & Koeficijent za preračun 1 - (red. br. 4. + red. br. 5. + red. br. 6 + red. br. 7) & 0,691 \\
\hline 9 & Neto plata (red. br. 1 x red. br. 2) & $95.254,19$ \\
\hline 10 & Bruto plata ((red. br. 9 - red. br. 3 x red. br. 4) / red. br. 8) & $\mathbf{1 3 7 . 8 4 9 , 7 6} \uparrow$ \\
\hline 11 & Porez (red. br. 10 - red. br. 3) x (red. br. 4.) & $\mathbf{1 3 . 7 8 4 , 9 8} \uparrow$ \\
\hline 12 & Doprinos za PIO na teret zaposlenog (red. br. 5 x red. br. 10) & $\mathbf{2 0 . 6 7 7 , 4 6} \uparrow$ \\
\hline 13 & Doprinos za zdr. osig. na teret zaposlenog (red. br. 6 x red. br. 10) & $\mathbf{7 . 0 9 9 , 2 6} \uparrow$ \\
\hline 14 & Dop. za osig. za sl. nez. na teret zaposlenog (red. br. 7 x red. br. 10) & $\mathbf{1 . 0 3 3 , 8 7 ~} \uparrow$ \\
\hline
\end{tabular}


Vojnoekonomski pregled

Tabela 10 - Obračun plate po neto osnovici bez poreske olakšice, sa smanjenom stopom doprinosa za penzijsko i invalidsko osiguranje na teret zaposlenog

\begin{tabular}{|c|c|c|}
\hline R. br. & Naziv & Iznos \\
\hline 1 & Neto osnovica & $17.101,29$ \\
\hline 2 & Koeficijent & 5,57 \\
\hline 3 & Poreska olakšica & 0,00 \\
\hline 4 & Stopa poreza na dohodak & $10,00 \%$ \\
\hline 5 & Stopa doprinosa za PIO na teret zaposlenog & $13,00 \% \downarrow$ \\
\hline 6 & Stopa doprinosa za zdr. osig. na teret zaposlenog & $5,15 \%$ \\
\hline 7 & Stopa doprinosa za osig. za sl. nez. na teret zaposlenog & $0,75 \%$ \\
\hline 8 & Koeficijent za preračun 1 - (red. br. $4 .+$ red. br. $5 .+$ red. br. $6+$ red. br. 7$)$ & 0,711 \\
\hline 9 & Neto plata (red. br. $1 \mathrm{x}$ red. br. 2) & $95.254,19$ \\
\hline 10 & Bruto plata ((red. br. 9 - red. br. 3 x red. br. 4) / red. br. 8) & $133.972,13$ \\
\hline 11 & Porez (red. br. 10 - red. br. 3) x (red. br. 4.) & $13.397,21 \downarrow$ \\
\hline 12 & Doprinos za PIO na teret zaposlenog (red. br. 5 x red. br. 10) & $17.416,38 \downarrow$ \\
\hline 13 & Doprinos za zdr. osig. na teret zaposlenog (red. br. 6 x red. br. 10) & $6.899,56 \downarrow$ \\
\hline 14 & Doprinos za osig. za sl. nez. na teret zaposlenog (red. br. 7 x red. br. 10) & $1.004,79 \downarrow$ \\
\hline
\end{tabular}

Na osnovu poređenja baznih rezultata i rezultata iz gornjih tabela, kod obračuna plate po neto osnovici, promena zbirne stope doprinosa na teret zaposlenog ${ }^{2}$ uz nepromenjenu visinu poreske stope i poreske olakšice ne menja visinu neto plate, a direktno utiče na kretanje visine bruto plate odnosno, na rast/smanjenje troškova poreza i doprinosa i samim time, ukupnog troška plate.

Tabela 11 - Obračun plate po bruto osnovici bez poreske olakšice, sa uvećanom stopom doprinosa za penzijsko i invalidsko osiguranje na teret zaposlenog

\begin{tabular}{|c|l|r|}
\hline R. br. & \multicolumn{1}{|c|}{ Naziv } & \multicolumn{1}{|c|}{ Iznos } \\
\hline $\mathbf{1}$ & Bruto osnovica & $\mathbf{2 4 . 3 9 5 , 5 6}$ \\
\hline 2 & Koeficijent & 5,57 \\
\hline 3 & Poreska olakšica & 0,00 \\
\hline 4 & Stopa poreza na dohodak & $10,00 \%$ \\
\hline $\mathbf{5}$ & Stopa doprinosa za PIO na teret zaposlenog & $\mathbf{1 5 , 0 0 \%} \uparrow$ \\
\hline 6 & Stopa doprinosa za zdr. osig. na teret zaposlenog & $5,15 \%$ \\
\hline 7 & Stopa doprinosa za osig. za sl. nez. na teret zaposlenog & $0,75 \%$ \\
\hline 8 & Koeficijent za preračun 1 - (red. br. 4. + red. br. 5. + red. br. 6 + red. br. 7) & 0,691 \\
\hline 9 & Bruto plata (red. br. 1 x red. br. 2) & $135.883,29$ \\
\hline 10 & Neto plata (red. br. 9 x red. br. 8 + red. br. 3 x red. br. 4 ) & $\mathbf{9 3 . 8 9 5 , 3 5} \downarrow$ \\
\hline 11 & Porez (red. br. 9 - red. br. 3) x (red. br. 4.) & $13.588,33$ \\
\hline $\mathbf{1 2}$ & Doprinos za PIO na teret zaposlenog (red. br. 5 x red. br. 9) & $\mathbf{2 0 . 3 8 2 , 4 9} \uparrow$ \\
\hline 13 & Doprinos za zdr. osig. na teret zaposlenog (red. br. 6 x red. br. 9) & $6.997,99$ \\
\hline 14 & Doprinos za osig. za sl. nez. na teret zaposlenog (red. br. 7 x red. br. 9) & $1.019,12$ \\
\hline
\end{tabular}

\footnotetext{
${ }^{2} \mathrm{U}$ situaciji kada se stopa jedne komponente doprinosa uveća za određeni procenat a stopa druge kompo-
} nente umanji za isti procenat, zbirna stopa doprinosa ostaje nepromenjena. 
Tabela 12 - Obračun plate po bruto osnovici bez poreske olakšice, sa umanjenom stopom doprinosa za penzijsko i invalidsko osiguranje

\begin{tabular}{|c|l|r|}
\hline R. br. & \multicolumn{1}{|c|}{ Naziv } & \multicolumn{1}{|c|}{ Iznos } \\
\hline 1 & Bruto osnovica & $24.395,56$ \\
\hline 2 & Koeficijent & 5,57 \\
\hline 3 & Poreska olakšica & 0,00 \\
\hline 4 & Stopa poreza na dohodak & $10,00 \%$ \\
\hline $\mathbf{5}$ & Stopa doprinosa za PIO na teret zaposlenog & $\mathbf{1 3 , 0 0 \%} \downarrow$ \\
\hline 6 & Stopa doprinosa za zdr. osig. na teret zaposlenog & $5,15 \%$ \\
\hline 7 & Stopa doprinosa za osig. za sl. nez. na teret zaposlenog & $0,75 \%$ \\
\hline 8 & $\begin{array}{l}\text { Koeficijent za preračun } \\
\text { - (red. br. 4. + red. br. 5. + red. br. 6 + red. br. 7) }\end{array}$ & 0,711 \\
\hline 9 & Bruto plata (red. br. 1 x red. br. 2) & $135.883,29$ \\
\hline 10 & $\begin{array}{l}\text { Neto plata } \\
\text { (red. br. 9 x red. br. 8 + red. br. 3 x red. br. 4) }\end{array}$ & $\mathbf{9 6 . 6 1 3 , 0 2} \uparrow$ \\
\hline 11 & Porez (red. br. 9 - red. br. 3) x (red. br. 4.) & $13.588,33$ \\
\hline 12 & Doprinos za PIO na teret zaposlenog (red. br. 5 x red. br. 9) & $\mathbf{1 7 . 6 6 4 , 8 3} \downarrow$ \\
\hline 13 & Doprinos za zdr. osig. na teret zaposlenog (red. br. 6 x red. br. 9) & $6.997,99$ \\
\hline 14 & Doprinos za osig. za sl. nez. na teret zaposlenog (red. br. 7 x red. br. 9) & $1.019,12$ \\
\hline
\end{tabular}

Na osnovu gornjih rezultata može se uočiti, kod metode obračuna plate po bruto osnovici, promena zbirne stope doprinosa na teret zaposlenog uz nepromenjenu visinu poreske stope i poreske olakšice ne menja bruto platu niti ukupan trošak plate, ali, uvećanjem/smanjenjem stope bilo koje komponente doprinosa dolazi do uvećanja/smanjenja iznosa te komponente doprinosa i smanjenja/uvećanja neto plate za isti iznos razlike (sa suprotnim predznakom).

Posmatrano sa aspekta kako je trenutno uređen sistem penzijskog osiguranja u Republici Srbiji i da je obračun penzijskog osnova srazmeran odnosu zarade zaposlenog prema prosečnoj zaradi izvedenoj iz mase zarada svih radno angažovanih lica u privrednim i vanprivrednim delatnostima (tj. od zarada/plata po bruto ili neto osnovici) za određeni period (uobičajeno za godinu dana), u situacijama kada se zbirna stopa doprinosa na teret zaposlenog uvećava (dok stopa poreza i poreska olakšica ostaju nepromenjene), lica koja primaju zaradu/platu po neto osnovici ostvaruju veće pravo na penzijsko osiguranje u odnosu na lica koja primaju zaradu/platu po bruto osnovici, pošto im uz istu neto platu bruto zarada/plata raste dok drugima stagnira uz manju neto platu. Kada zbirna stopa doprinosa na teret zaposlenog opada (poreska stopa i poreska olakšica se ne menjaju) bruto zarada/plata po neto osnovici se smanjuje utičući u svom segmentu na manju visinu prosečne bruto zarade, omogućujući veća prava na penzijsko osiguranje licima kojima se bruto zarada/plata obračunava po bruto osnovici. 


\section{Uticaj promene poreske stope}

Kao što se moglo zaključiti i u slučaju promene stope doprinosa na teret zaposlenog, promena stope poreza (uz nepromenjenu zbirnu stopu doprinosa na teret zaposlenog i nepromenjenu visinu poreske olakšice) kod metode obračuna plate po neto osnovici direktno utiče na kretanje bruto plate odnosno troškova poreza i doprinosa, pri čemu neto plata ostaje nepromenjena.

Tabela 13 - Obračun plate po neto osnovici bez poreske olakšice, uz uvećanje poreske stope

\begin{tabular}{|c|l|r|}
\hline R. br. & \multicolumn{1}{|c|}{ Naziv } & \multicolumn{1}{|c|}{ Iznos } \\
\hline 1 & Neto osnovica & $17.101,29$ \\
\hline 2 & Koeficijent & 5,57 \\
\hline 3 & Poreska olakšica & 0,00 \\
\hline 4 & Stopa poreza na dohodak & $12,00 \% \uparrow$ \\
\hline 5 & Stopa doprinosa za PIO na teret zaposlenog & $14,00 \%$ \\
\hline 6 & Stopa doprinosa za zdr. osig. na teret zaposlenog & $5,15 \%$ \\
\hline 7 & Stopa doprinosa za osig. za sl. nez. na teret zaposlenog & $0,75 \%$ \\
\hline 8 & Koeficijent za preračun 1 - (red. br. 4. + red. br. 5. + red. br. 6 + red. br. 7) & 0,681 \\
\hline 9 & Neto plata (red. br. 1 x red. br. 2) & $95.254,19$ \\
\hline 10 & Bruto plata ((red. br. 9 - red. br. 3 x red. br. 4) / red. br. 8) & $139.873,99 \uparrow$ \\
\hline 11 & Porez (red. br. 10 - red. br. 3) x (red. br. 4.) & $16.784,88 \uparrow$ \\
\hline 12 & Doprinos za PIO na teret zaposlenog (red. br. 5 x red. br. 10) & $19.582,36 \uparrow$ \\
\hline 13 & Doprinos za zdr. osig. na teret zaposlenog (red. br. 6 x red. br. 10) & $\mathbf{7 . 2 0 3 , 5 1 \uparrow}$ \\
\hline 14 & Doprinos za osig. za sl. nez. na teret zaposlenog (red. br. 7 x red. br. 10) & $\mathbf{1 . 0 4 9 , 0 5 \uparrow}$ \\
\hline
\end{tabular}

Tabela 14 - Obračun plate po neto osnovici bez poreske olakšice, uz umanjenje poreske stope

\begin{tabular}{|c|c|c|}
\hline R. br. & Naziv & Iznos \\
\hline 1 & Neto osnovica & $17.101,29$ \\
\hline 2 & Koeficijent & 5,57 \\
\hline 3 & Poreska olakšica & 0,00 \\
\hline 4 & Stopa poreza na dohodak & $8,00 \% \downarrow$ \\
\hline 5 & Stopa doprinosa za PIO na teret zaposlenog & $14,00 \%$ \\
\hline 6 & Stopa doprinosa za zdr. osig. na teret zaposlenog & $5,15 \%$ \\
\hline 7 & Stopa doprinosa za osig. za sl. nez. na teret zaposlenog & $0,75 \%$ \\
\hline 8 & Koeficijent za preračun 1 - (red. br. 4. + red. br. 5. + red. br. 6 + red. br. 7) & 0,721 \\
\hline 9 & Neto plata (red. br. $1 \mathrm{x}$ red. br. 2) & $95.254,19$ \\
\hline 10 & Bruto plata ((red. br. 9 - red. br. 3 x red. br. 4) / red. br. 8) & $132.113,99 \downarrow$ \\
\hline 11 & Porez (red. br. 10 - red. br. 3) x (red. br. 4.) & $10.569,12 \downarrow$ \\
\hline 12 & Doprinos za PIO na teret zaposlenog (red. br. 5 x red. br. 10) & $18.495,96 \downarrow$ \\
\hline 13 & Doprinos za zdr. osig. na teret zaposlenog (red. br. 6 x red. br. 10) & $6.803,87 \downarrow$ \\
\hline 14 & Doprinos za osig. za sl. nez. na teret zaposlenog (red. br. 7 x red. br. 10) & $990,85 \downarrow$ \\
\hline
\end{tabular}


Tabela 15 - Obračun plate po bruto osnovici bez poreske olakšice, uz uvećanje poreske stope

\begin{tabular}{|c|l|r|}
\hline R. br. & \multicolumn{1}{|c|}{ Naziv } & \multicolumn{1}{|c|}{ Iznos } \\
\hline 1 & Bruto osnovica & $\mathbf{2 4 . 3 9 5 , 5 6}$ \\
\hline 2 & Koeficijent & 5,57 \\
\hline 3 & Poreska olakšica & 0,00 \\
\hline 4 & Stopa poreza na dohodak & $\mathbf{1 2 , 0 0 \%} \uparrow$ \\
\hline 5 & Stopa doprinosa za PIO na teret zaposlenog & $14,00 \%$ \\
\hline 6 & Stopa doprinosa za zdr. osig. na teret zaposlenog & $5,15 \%$ \\
\hline 7 & Stopa doprinosa za osig. za sl. nez. na teret zaposlenog & $0,75 \%$ \\
\hline 8 & Koeficijent za preračun 1 - (red. br. 4. + red. br. 5. + red. br. 6 + red. br. 7) & 0,681 \\
\hline 9 & Bruto plata (red. br. 1 x red. br. 2) & $135.883,29$ \\
\hline 10 & Neto plata (red. br. 9 x red. br. 8 + red. br. 3 x red. br. 4) & $\mathbf{9 2 . 5 3 6 , 5 2} \downarrow$ \\
\hline 11 & Porez (red. br. 9 - red. br. 3) x (red. br. 4.) & $\mathbf{1 6 . 3 0 5 , 9 9} \uparrow$ \\
\hline 12 & Doprinos za PIO na teret zaposlenog (red. br. 5 x red. br. 9) & $19.023,66$ \\
\hline 13 & Doprinos za zdr. osig. na teret zaposlenog (red. br. 6 x red. br. 9) & $6.997,99$ \\
\hline 14 & Doprinos za osig. za sl. nez. na teret zaposlenog (red. br. 7 x red. br. 9) & $1.019,12$ \\
\hline
\end{tabular}

Tabela 16 - Obračun plate po bruto osnovici bez poreske olakšice, uz uvećanje poreske stope

\begin{tabular}{|c|l|r|}
\hline R. br. & \multicolumn{1}{|c|}{ Naziv } & \multicolumn{1}{|c|}{ Iznos } \\
\hline 1 & Bruto osnovica & $24.395,56$ \\
\hline 2 & Koeficijent & 5,57 \\
\hline 3 & Poreska olakšica & 0,00 \\
\hline 4 & Stopa poreza na dohodak & $\mathbf{8 , 0 0 \%} \downarrow$ \\
\hline 5 & Stopa doprinosa za PIO na teret zaposlenog & $14,00 \%$ \\
\hline 6 & Stopa doprinosa za zdr. osig. na teret zaposlenog & $5,15 \%$ \\
\hline 7 & Stopa doprinosa za osig. za sl. nez. na teret zaposlenog & $0,75 \%$ \\
\hline 8 & Koeficijent za preračun 1 - (red. br. 4. + red. br. 5. + red. br. 6 + red. br. 7) & 0,721 \\
\hline 9 & Bruto plata (red. br. 1 x red. br. 2) & $135.883,29$ \\
\hline 10 & Neto plata (red. br. 9 x red. br. 8 + red. br. 3 x red. br. 4 ) & $\mathbf{9 7 . 9 7 1 , 8 5} \uparrow$ \\
\hline 11 & Porez (red. br. 9 - red. br. 3) x (red. br. 4.) & $\mathbf{1 0 . 8 7 0 , 6 6} \downarrow$ \\
\hline 12 & Doprinos za PIO na teret zaposlenog (red. br. 5 x red. br. 9) & $19.023,66$ \\
\hline 13 & Doprinos za zdr. osig. na teret zaposlenog (red. br. 6 x red. br. 9) & $6.997,99$ \\
\hline 14 & Doprinos za osig. za sl. nez. na teret zaposlenog (red. br. 7 x red. br. 9) & $1.019,12$ \\
\hline
\end{tabular}


Kod metode obračuna plate po bruto osnovici, promena stope poreza (uz nepromenjenu visinu zbirne stope doprinosa na teret zaposlenog i nepromenjenu visinu poreske olakšice) direktno utiče na visinu poreza a obrnuto na visinu neto plate, za isti iznos razlike sa suprotnim predznakom (apsolutna vrednost razlike između visine poreza pre promene i visine poreza nakon promene poreske stope jednaka je vrednosti razlike kod neto plate pre i posle promene).

\section{Uticaj poreske olakšice}

Uvođenjem poreske olakšice, kod obračuna plate po neto osnovici, bruto plata odnosno visina obaveze po osnovu poreza i doprinosa se smanjuju, a neto plata ostaje nepromenjena. U slučaju obračuna plate po bruto osnovici, uvođenjem poreske olakšice bruto plata ostaje nepromenjena, a smanjuje se obaveza po osnovu plaćanja poreza uz istovremeno povećanje neto plate licu, za isti iznos razlike sa suprotnim predznakom (apsolutna vrednost razlike između visine neto plate pre poreske olakšice i visine neto plate nakon poreske olakšice ista je vrednosti razlike visine poreza pre i nakon primene poreske olakšice).

Tabela 17 - Obračun plate po neto osnovici sa poreskom olakšicom

\begin{tabular}{|c|l|r|}
\hline R. br. & \multicolumn{1}{|c|}{ Naziv } & \multicolumn{1}{|c|}{ Iznos } \\
\hline 1 & Neto osnovica & $17.101,29$ \\
\hline 2 & Koeficijent & 5,57 \\
\hline 3 & Poreska olakšica & $11.604,00$ \\
\hline 4 & Stopa poreza na dohodak & $10,00 \%$ \\
\hline 5 & Stopa doprinosa za PIO na teret zaposlenog & $14,00 \%$ \\
\hline 6 & Stopa doprinosa za zdr. osig. na teret zaposlenog & $5,15 \%$ \\
\hline 7 & Stopa doprinosa za osig. za sl. nez. na teret zaposlenog & $0,75 \%$ \\
\hline 8 & $\begin{array}{l}\text { Koeficijent za preračun } \\
1 \text { - (red. br. 4. + red. br. 5. + red. br. 6 + red. br. 7) }\end{array}$ & 0,701 \\
\hline 9 & Neto plata (red. br. 1 x red. br. 2) & $95.254,19$ \\
\hline 10 & Bruto plata (red. br. 9 - 1160,40) / (red. br. 8) & $134.227,94 \downarrow$ \\
\hline 11 & Porez (red. br. 10 - red. br. 3) x (red. br. 4.) & $\mathbf{1 2 . 2 6 2 , 3 9} \downarrow$ \\
\hline 12 & Doprinos za PIO na teret zaposlenog (red. br. 5 x red. br. 10) & $\mathbf{1 8 . 7 9 1 , 9 1 \downarrow}$ \\
\hline 13 & Doprinos za zdr. osig. na teret zaposlenog (red. br. 6 x red. br. 10) & \multicolumn{1}{|c|}{ (12,74 $\downarrow$} \\
\hline 14 & Doprinos za osig. za sl. nez. na teret zaposlenog (red. br. 7 x red. br. 10) \\
\hline
\end{tabular}


Tabela 18 - Obračun plate po bruto osnovici sa poreskom olakšicom

\begin{tabular}{|c|l|r|}
\hline R. br. & \multicolumn{1}{|c|}{ Naziv } & \multicolumn{1}{|c|}{ Iznos } \\
\hline 1 & Bruto osnovica & $\mathbf{2 4 . 3 9 5 , 5 6}$ \\
\hline 2 & Koeficijent & 5,57 \\
\hline 3 & Poreska olakšica & $\mathbf{1 1 . 6 0 4 , 0 0}$ \\
\hline 4 & Stopa poreza na dohodak & $10,00 \%$ \\
\hline 5 & Stopa doprinosa za PIO na teret zaposlenog & $14,00 \%$ \\
\hline 6 & Stopa doprinosa za zdr. osig. na teret zaposlenog & $5,15 \%$ \\
\hline 7 & Stopa doprinosa za osig. za sl. nez. na teret zaposlenog & $0,75 \%$ \\
\hline 8 & Koeficijent za preračun & 0,701 \\
\hline 9 & Bruto plata (red. br. 1 x red. br. 2) & $135.883,29$ \\
\hline 10 & Neto plata (red. br. 9 x red. br. 8 + red. br. 3 x red. br. 4) & $\mathbf{9 6 . 4 1 4 , 5 9} \uparrow$ \\
\hline 11 & Porez (red. br. 9 - red. br. 3) x (red. br. 4.) & $12.427,93$ \\
\hline 12 & Doprinos za PIO na teret zaposlenog (red. br. 5 x red. br. 9) & $19.023,66$ \\
\hline 13 & Doprinos za zdr. osig. na teret zaposlenog (red. br. 6 x red. br. 9) & $6.997,99$ \\
\hline 14 & Doprinos za osig. za sl. nez. na teret zaposlenog (red. br. 7 x red. br. 9) & $1.019,12$ \\
\hline
\end{tabular}

Svako dalje povećanje poreske olakšice proizvodi isti efekat odnosno smanjenje poreske olakšice inicira obrnuti efekat.

\section{Primena minimalne zarade, najniže i najviše osnovice za plaćanje doprinosa}

Minimalna zarada (Zakon o radu, čl. 112) je najniža cena po satu rada (uobičajeno je određena u neto iznosu odakle se preračunava u bruto iznos) koju imaju obavezu da primenjuju svi poslodavci čije je sedište registrovano na teritoriji Srbije. Budući da se ista primenjuje i u situacijama kada lice prima naknadu plate za opravdano odsustvovanje sa posla (bolovanje, usavršavanje, na poziv drugog državnog organa itd), može se zaključiti da troškovi plate i naknade plate po licu ne mogu biti niži od cene koštanja minimalne zarade (bruto minimalna zarada sa doprinosima na teret poslodavca). U slučaju primene minimalne zarade, kod obe metode obračuna iznos neto i bruto plate ostaje isti.

U situacijama kada zaposleni neopravdano odsustvuje sa posla, ili je udaljen od rada, ili se nalazi u pritvoru, kada lice neće ostvarivati naknadu plate odnosno ostvarivaće određenu naknadu u neto iznosu nižem od minimalne zarade, mesečni doprinosi se po zakonskoj obavezi moraju platiti po najnižoj mesečnoj osnovici za plaćanje doprinosa (sve dok se lice nalazi u radnom odnosu). 
U slučaju primene najniže mesečne osnovice za plaćanje doprinosa, formula za obračun bruto prihoda izgledala bi po sledećem:

1) Bruto prihod $=$ Neto iznos + Porez + Doprinosi na teret zaposlenog;

2) Bruto prihod $=$ Neto iznos $+0,1 \times$ (Bruto prihod -11.604$)+0,199 \times$ Najniža osnovica;

3) Bruto prihod $=$ Neto iznos + 0,1 x Bruto prihod $-1.160,4+0,199 \times$ Najniža osnovica;

4) Bruto prihod $x(1-0,1)=$ Neto iznos $-1.160,4+0,199 \times$ Najniža osnovica;

5) Bruto prihod $\times 0,9=$ Neto iznos $-1.160,4+0,199 \times$ Najniža osnovica;

6) Bruto prihod $=($ Neto iznos $-1.160,4+0,199 \times$ Najniža osnovica) $/ 0,9$;

Kada se naknada ne odnosi na ceo mesec, koristi se srazmeran iznos poreske olakšice. Srazmeran iznos najniže mesečne osnovice za plaćanje doprinosa se određuje samo u slučaju da lice radi kod dva ili više poslodavaca. Obračun bruto prihoda izgledao bi po sledećem:

$$
\mathrm{BP}=\frac{\mathrm{N}-1.160,4 \times \check{c} / \mathrm{mc}+(\mathrm{NžmO} \times 19,9 \%)}{0,9}
$$

BP - Bruto prihod (neto iznos sa porezom i doprinosima na teret zaposlenog),

$\mathrm{N}$ - Pripadajući neto iznos za isplatu,

č - broj časova za koje pripada neto iznos,

mč - mesečni fond sati rada u mesecu,

NžmO - Najniža mesečna osnovica za plaćanje doprinosa.

Kako se kod budžetskih korisnika najniža mesečna osnovica za plaćanje doprinosa koristi u specifičnim situacijama, ne može se odrediti opšte pravilo u poreskim implikacijama u zavisnosti od metode obračuna plate. Posebno je problematično, kod slučaja obračuna plate po bruto osnovici, logikom računske operacije usled uvećanja doprinosa pri nepromenjenoj bruto naknadi treba smanjiti neto iznos za isplatu, što ugrožava egzistenciju lica, pa se često u praksi primenjuju različita pravna rešenja radi prevazilaženja ovakvih situacija.

Obaveza primene najviše mesečne osnovice za plaćanje doprinosa kod budžetskih korisnika može nastupiti kada se licu pored redovne plate isplaćuje naknada za neiskorišćeni godišnji odmor u visini mesečne plate (sastavlja se jedna PPPO gde se pod istom šifrom vrste prihoda za zaradu, prijavljuje prihod po osnovu redovne plate i naknade za isti obračunski period, obzirom da se naknada ne može prijaviti za raniji obračunski period). U slučaju primene najviše osnovice za plaćanje doprinosa, formula za obračun bruto prihoda izgledala bi po sledećem:

$$
\mathrm{BP}=\frac{\mathrm{N}-1.160,4 \times \check{\mathrm{c}} / \mathrm{mc}+(\mathrm{NvmO} \times 19,9 \%)}{0,9}
$$

BP - Bruto prihod (neto iznos sa porezom i doprinosima na terete zaposlenog),

$\mathrm{N}$ - Pripadajući neto iznos za isplatu,

č - broj časova za koje pripada neto iznos,

mč - mesečni fond sati rada u mesecu,

NvmO - Najviša mesečna osnovica za plaćanje doprinosa.

I u ovom slučaju, kada se bruto prihod ne odnosi na ceo mesec, koristi se srazmeran iznos poreske olakšice. Sa druge strane, propisani iznos najviše mesečne osnovice za plaćanje doprinosa koristi se u punom iznosu za jedno lice bez obzira da li lice prima prihod za ceo mesec ili deo meseca. Ukoliko lice radi kod više poslodavaca, određuje se srazmeran iznos najviše osnovice, shodno stepenu angažovanosti lica kod poslodavca u odnosu na puno radno vreme. 
Primena najviše osnovice za plaćanje doprinosa izaziva različite efekte u zavisnosti od metode obračuna plate. Kod metode obračuna plate po neto osnovici, efekat se može sagledati poređenjem rezultata kod primera gde se najviša osnovica nije koristila i primera gde je primenjena.

Tabela 19 - Obračun plate po neto osnovici bez primene najviše mesečne osnovice za plaćanje doprinosa

\begin{tabular}{|c|l|r|}
\hline R. br. & \multicolumn{1}{|c|}{ Naziv } & \multicolumn{1}{|c|}{ Iznos } \\
\hline 1 & Neto osnovica & $17.101,29$ \\
\hline 2 & Koeficijent & 7,11 \\
\hline 3 & Poreska olakšica & $11.604,00$ \\
\hline 4 & Stopa poreza na dohodak & $10,00 \%$ \\
\hline 5 & Stopa doprinosa za PIO na teret zaposlenog & $14,00 \%$ \\
\hline 6 & Stopa doprinosa za zdr. osig. na teret zaposlenog & $5,15 \%$ \\
\hline 7 & Stopa doprinosa za osig. za sl. nez. na teret zaposlenog & $0,75 \%$ \\
\hline 8 & Neto plata (red. br. 1 x red. br. 2) & $121.590,17$ \\
\hline 9 & Neto naknada za neiskorišćeni godišnji odmor & $121.590,17$ \\
\hline 10 & $\begin{array}{l}\text { Bruto prihod (red. br. 8 + red. br. 9 - red. br. 3 x red. br. 4) I } \\
\text { (1 - (red. br. 4 + red. br. 5 + red. br. 6 + red. br. 7)) }\end{array}$ & $\mathbf{3 4 5 . 2 4 9 , 5 6}$ \\
\hline 11 & Porez (red. br. 10 - red. br. 3) x (red. br. 4.) & $33.364,56$ \\
\hline 12 & Osnovica za plaćanje doprinosa (red. br. 10) & $345.249,56$ \\
\hline 13 & Doprinos za PIO na teret zaposlenog (red. br. 5 x red. br. 12) & $48.334,94$ \\
\hline 14 & Doprinos za zdr. osig. na teret zaposlenog (red. br. 6 x red. br. 12) & $17.780,35$ \\
\hline 15 & Doprinos za osig. za sl. nez. na teret zaposlenog (red. br. 7 x red. br. 12) & $2.589,37$ \\
\hline 16 & Neto prihod (red. br. 10 - (red. br. 11 + red. br. 13 + red. br. 14 + red. br. 15)) & $\mathbf{2 4 3 . 1 8 0 , 3 4}$ \\
\hline
\end{tabular}

Tabela 20 - Obračun plate po neto osnovici sa primenom najviše mesečne osnovice za plaćanje doprinosa

\begin{tabular}{|r|l|r|}
\hline R. br. & \multicolumn{1}{|c|}{ Naziv } & \multicolumn{1}{|c|}{ Iznos } \\
\hline 1 & Neto osnovica & $17.101,29$ \\
\hline 2 & Koeficijent & 7,11 \\
\hline 3 & Poreska olakšica & $11.604,00$ \\
\hline 4 & Stopa poreza na dohodak & $10,00 \%$ \\
\hline 5 & Stopa doprinosa za PIO na teret zaposlenog & $14,00 \%$ \\
\hline 6 & Stopa doprinosa za zdr. osig. na teret zaposlenog & $5,15 \%$ \\
\hline 7 & Stopa doprinosa za osig. za sl. nez. na teret zaposlenog & $0,75 \%$ \\
\hline 8 & Neto plata (red. br. 1 x red. br. 2) & $121.590,17$ \\
\hline 9 & Neto naknada za neiskorišćeni godišnji odmor & $121.590,17$ \\
\hline 10 & Bruto prihod (red. br. 8 + red. br. 9 - red. br. 3 x red. br. 4+red. br. 12 x & $\mathbf{3 3 6 . 6 5 8 , 3 9} \downarrow$ \\
\hline 11 & Porez (red. br. 10 - red. br. 3) x (red. br. 4.) & $\mathbf{3 2 . 5 0 5 , 4 4} \downarrow$ \\
\hline 12 & Najviša mesečna osnovica za plaćanje doprinosa za mesec april 2016 & $306.395,00$ \\
\hline 13 & Doprinos za PIO na teret zaposlenog (red. br. 5 x red. br. 12) & $\mathbf{4 2 . 8 9 5 , 3 0} \downarrow$ \\
\hline 14 & Doprinos za zdr. osig. na teret zaposlenog (red. br. 6 x red. br. 12) & $\mathbf{1 5 . 7 7 9 , 3 4} \downarrow$ \\
\hline 15 & Doprinos za osig. za sl. nez. na teret zaposlenog (red. br. 7 x red. br. 12) & $\mathbf{2 . 2 9 7 , 9 6} \downarrow$ \\
\hline 16 & Neto prihod (red. br. 10 - (red. br. 11 + red. br. 13 + red. br. 14 + red. br. 15)) & $\mathbf{2 4 3 . 1 8 0 , 3 4}$ \\
\hline
\end{tabular}


Kao što se može uočiti u gornjim primerima, usled primene najviše mesečne osnovice za plaćanje doprinosa kod slučaja obračuna plate po neto osnovici, smanjuju se bruto prihod, osnovica za plaćanje poreza, osnovica za plaćanje doprinosa, troškovi poreza i doprinosa, uz nepromenjeni neto prihod licu. Kod metode obračuna plate po bruto osnovici, efekti primene najviše mesečne osnovice za plaćanje doprinose se takođe mogu sagledati kroz primere:

Tabela 21 - Obračun plate po bruto osnovici bez primene najviše mesečne osnovice za plaćanje doprinosa

\begin{tabular}{|r|l|r|}
\hline R. br. & \multicolumn{1}{|c|}{ Naziv } & \multicolumn{1}{|c|}{ Iznos } \\
\hline 1 & Bruto osnovica & $\mathbf{2 4 . 2 7 9 , 1 5}$ \\
\hline 2 & Koeficijent & 7,11 \\
\hline 3 & Poreska olakšica & $11.604,00$ \\
\hline 4 & Stopa poreza na dohodak & $10,00 \%$ \\
\hline 5 & Stopa doprinosa za PIO na teret zaposlenog & $14,00 \%$ \\
\hline 6 & Stopa doprinosa za zdr. osig. na teret zaposlenog & $5,15 \%$ \\
\hline 7 & Stopa doprinosa za osig. za sl. nez. na teret zaposlenog & $0,75 \%$ \\
\hline 8 & Bruto plata (red. br. 1 x red. br. 2) & $172.624,78$ \\
\hline 9 & Bruto naknada za neiskorišćeni godišnji odmor & $172.624,78$ \\
\hline 10 & Bruto prihod (red. br. 8 + red. br. 9) & $345.249,56$ \\
\hline 11 & Porez (red. br. 10 - red. br. 3) x (red. br. 4.) & $33.364,56$ \\
\hline 12 & Osnovica za plaćanje doprinosa (red. br. 10) & $345.249,56$ \\
\hline 13 & Doprinos za PIO na teret zaposlenog (red. br. 5 x red. br. 12) & $48.334,94$ \\
\hline 14 & Doprinos za zdr. osig. na teret zaposlenog (red. br. 6 x red. br. 12) & $17.780,35$ \\
\hline 15 & Doprinos za osig. za sl. nez. na teret zaposlenog (red. br. 7 x red. br. 12) & $2.589,37$ \\
\hline 16 & Neto prihod (red. br. 10 - (red. br. 11 + red. br. 13 + red. br. 14 + red. br. 15)) & $\mathbf{2 4 3 . 1 8 0 , 3 4}$ \\
\hline
\end{tabular}

Tabela 22 - Obračun plate po bruto osnovici sa primenom najviše mesečne osnovice za plaćanje doprinosa

\begin{tabular}{|c|l|r|}
\hline R. br. & \multicolumn{1}{|c|}{ Naziv } & \multicolumn{1}{c|}{ Iznos } \\
\hline 1 & Bruto osnovica & $\mathbf{2 4 . 2 7 9 , 1 5}$ \\
\hline 2 & Koeficijent & 7,11 \\
\hline 3 & Poreska olakšica & $11.604,00$ \\
\hline 4 & Stopa poreza na dohodak & $10,00 \%$ \\
\hline 5 & Stopa doprinosa za PIO na teret zaposlenog & $14,00 \%$ \\
\hline 6 & Stopa doprinosa za zdr. osig. na teret zaposlenog & $5,15 \%$ \\
\hline 7 & Stopa doprinosa za osig. za sl. nez. na teret zaposlenog & $0,75 \%$ \\
\hline $\mathbf{8}$ & Bruto plata (red. br. 1 x red. br. 2) & $172.624,78$ \\
\hline 9 & Bruto naknada za neiskorišćeni godišnji odmor & $172.624,78$ \\
\hline 10 & Bruto prihod (red. br. 8 + red. br. 9) & $345.249,56$ \\
\hline 11 & Porez (red. br. 10 - red. br. 3) x (red. br. 4.) & $33.364,56$ \\
\hline 12 & Najviša mesečna osnovica za plaćanje doprinosa & $\mathbf{3 0 6 . 3 9 5 , 0 0}$ \\
\hline 13 & Doprinos za PIO na teret zaposlenog (red. br. 5 x red. br. 12) & $\mathbf{4 2 . 8 9 5 , 3 0} \downarrow$ \\
\hline 14 & Doprinos za zdr. osig. na teret zaposlenog (red. br. 6 x red. br. 12) & $\mathbf{1 5 . 7 7 9 , 3 4} \downarrow$ \\
\hline 15 & Doprinos za osig. za sl. nez. na teret zaposlenog (red. br. 7 x red. br. 12) & $\mathbf{2 . 2 9 7 , 9 6} \downarrow$ \\
\hline 16 & Neto prihod (red. br. 10 - (red. br. 11 + red. br. 13 + red. br. 14 + red. br. 15)) & $\mathbf{2 5 0 . 9 1 2 , 4 0 \uparrow}$ \\
\hline
\end{tabular}


Za razliku od slučaja obračuna plate po neto osnovici, primena najviše mesečne osnovice za plaćanje doprinosa kod metode obračuna plate po bruto osnovici ne menja bruto iznos za isplatu, s tim da se za isti iznos smanjuju doprinosi na teret zaposlenog odnosno uvećava neto prohod. Takođe, iako je bruto prihod ostao nepromenjen, troškovi doprinosa na teret poslodavca su se takođe smanjili usled plaćanja po manjem iznosu osnovice, tako da je ukupan trošak plate smanjen i u slučaju obračuna plate po bruto osnovici.

\section{Razlike između rekapitulacije plate kod akontacije i konačnog obračuna u odnosu na rekapitulaciju po poreskoj prijavi}

Kod najvećeg broja budžetskih korisnika, obračun akontacije plate sprovodi se po osnovu evidencije prisustva na radu za prvih petnaest dana koji se obračunskoj službi dostavlja elektronski (uz elektronski potpis) bez priloga (doznaka, rešenja itd) a koji se dostavljaju uz konačni obračun.

Primer akontacije plate za nekoliko desetina hiljada lica, po redovnom obračunu osnovnih elemenata plate, naknade i određenih dodataka može se ilustrovati na sledeći način:

Tabela 23 - Rekapitulacija akontacije plate

\begin{tabular}{|c|c|c|c|c|}
\hline Plata za rad & Dodatak za minuli rad & Dodatak za rad noću & $\begin{array}{l}\text { Dodatak za rad u } \\
\text { dane državnih } \\
\text { praznika koji nisu } \\
\text { radni dani }\end{array}$ & $\begin{array}{c}\text { Dodatak za } \\
\text { prekovremeni rad }\end{array}$ \\
\hline $599.859 .700,73$ & $39.655 .976,21$ & 0,00 & 0,00 & $499.564,37$ \\
\hline $\begin{array}{c}\text { Dodatak za dodatno } \\
\text { opterećenje }\end{array}$ & $\begin{array}{l}\text { Paušalni dodatak na } \\
\text { platu }\end{array}$ & $\begin{array}{l}\text { Dodatak za } \\
\text { pripravnost }\end{array}$ & $\begin{array}{l}\text { Naknada za vreme } \\
\text { udaljenja od rada }\end{array}$ & $\begin{array}{c}\text { Naknada plate za } \\
\text { vreme privremene } \\
\text { sprečenosti za rad } \\
\text { na teret } \\
\text { poslodavca }\end{array}$ \\
\hline $135.293,00$ & 0,00 & $178.417,02$ & $726.548,56$ & 0,00 \\
\hline $\begin{array}{c}\text { Naknada za } \\
\text { neiskorišćeni godišnji } \\
\text { odmor }\end{array}$ & $\begin{array}{l}\text { Naknada plate za } \\
\text { vreme korišćenja } \\
\text { godišnjeg odmora i } \\
\text { drugog plaćenog } \\
\text { odsustva }\end{array}$ & $\begin{array}{l}\text { Naknada plate za } \\
\text { vreme odsustva za } \\
\text { dane državnog } \\
\text { praznika }\end{array}$ & $\begin{array}{c}\text { Naknada plate za } \\
\text { vreme sprečenosti za } \\
\text { rad (bolovanja) na } \\
\text { teret Fonda }\end{array}$ & $\begin{array}{l}\text { Naknada plate za } \\
\text { odsustvo tokom } \\
\text { školovanja i } \\
\text { usavršavanja }\end{array}$ \\
\hline 0,00 & 0,00 & 0,00 & $12.266 .547,34$ & $5.623 .457,82$ \\
\hline $\begin{array}{l}\text { Naknada plate za } \\
\text { neraspoređena lica }\end{array}$ & $\begin{array}{c}\text { Naknada plate za lica } \\
\text { na raspolaganju }\end{array}$ & $\begin{array}{c}\text { Dodatak na platu za } \\
\text { ostvarene rezultate u } \\
\text { radu }\end{array}$ & $\begin{array}{c}\text { Bruto (neto sa } \\
\text { porezom i } \\
\text { doprinosima na teret } \\
\text { zaposlenog }\end{array}$ & Neto \\
\hline $997.854,12$ & $12.345 .698,79$ & 0,00 & $672.289 .057,95$ & $484.661 .145,89$ \\
\hline Osnovica za porez & Osnovica za doprinose & $\begin{array}{c}\text { Dodatni doprinos za } \\
\text { PIO }\end{array}$ & Porez & Obustave \\
\hline $538.423 .895,30$ & $672.289 .057,95$ & $38.415 .762,20$ & $53.842 .389,53$ & $66.472 .815,23$ \\
\hline
\end{tabular}


Vojnoekonomski pregled

\begin{tabular}{|c|c|c|c|c|}
\hline Plata za rad & Dodatak za minuli rad & Dodatak za rad noću & $\begin{array}{l}\text { Dodatak za rad u } \\
\text { dane državnih } \\
\text { praznika koji nisu } \\
\text { radni dani }\end{array}$ & $\begin{array}{c}\text { Dodatak za } \\
\text { prekovremeni rad }\end{array}$ \\
\hline $\begin{array}{c}\text { Doprinos za PIO na } \\
\text { teret zaposlenog }\end{array}$ & $\begin{array}{c}\text { Doprinos za } \\
\text { zdravstveno osiguranje } \\
\text { na teret zaposlenog }\end{array}$ & $\begin{array}{l}\text { Doprinos u slučaju } \\
\text { nezaposlenosti na } \\
\text { teret zaposlenog }\end{array}$ & $\begin{array}{l}\text { Zbirni doprinosi na } \\
\text { teret zaposlenog }\end{array}$ & $\begin{array}{l}\text { Neto za isplatu na } \\
\text { tek. rač. banaka }\end{array}$ \\
\hline $94.120 .468,11$ & $34.622 .886,48$ & $5.042 .167,93$ & $133.785 .522,53$ & 418.188.330,66 \\
\hline $\begin{array}{c}\text { Doprinos za PIO na } \\
\text { teret poslodavca }\end{array}$ & $\begin{array}{c}\text { Doprinos za } \\
\text { zdravstveno osiguranje } \\
\text { na teret poslodavca }\end{array}$ & $\begin{array}{l}\text { Doprinos u slučaju } \\
\text { nezaposlenosti na } \\
\text { teret zaposlenog }\end{array}$ & $\begin{array}{l}\text { Zbirni doprinosi na } \\
\text { teret poslodavca }\end{array}$ & $\begin{array}{c}\text { Cena koštanja } \\
\text { (Bruto sa } \\
\text { doprinosima na } \\
\text { teret poslodavca) }\end{array}$ \\
\hline $80.674 .686,95$ & $34.622 .886,48$ & $5.042 .167,93$ & $159.815 .854,53$ & $832.104 .912,48$ \\
\hline
\end{tabular}

Nakon etape redovnog obračuna akontacije, softverski se pristupa pripremi i izradi PPPO koja posle proračuna iznosa generiše sledeću rekapitulaciju:

\begin{tabular}{|c|c|c|c|c|c|c|c|}
\hline Bprihod & Osn.Porez & Porez & Osn. Dopr & PIO & Zdr. osig & NZS. & Ben. Staž \\
\hline $672.289 .057,95$ & $538.423 .895,30$ & $53.842 .389,53$ & $690.804 .699,82$ & $179.609 .221,95$ & $71.152 .884,08$ & $10.362 .070,50$ & $39.476 .113,16$ \\
\hline
\end{tabular}

Poredeći rekapitulaciju poreza i doprinosa iz poreske prijave sa rekapitulacijom iz akontacije, uočava se da je ukupna osnovica za plaćanje doprinosa u poreskoj prijavi viša, usled čega je viši iznos doprinosa (na teret zaposlenog i poslodavca), zbog lica kojima je polovina bruto plate ili naknade plate niža od najniže mesečne osnovice za plaćanje doprinosa. Naime, iako je plata po elementima iz rešenja i trenutno važećoj osnovici za obračun plate za sva lica viša od najniže mesečne osnovice za plaćanje doprinosa, članom 52. Zakona o doprinosima propisano je da "ako se zarada isplaćuje u delovima, a prvi deo zarade je manji od najniže mesečne osnovice doprinosa, poslodavac je dužan da prilikom isplate prvog dela zarade, obračuna i plati doprinose na najnižu mesečnu osnovicu doprinosa", zbog čega se prilikom isplate akontacije doprinosi plaćaju na osnovicu koja ne može biti niža od najniže mesečne osnovice za plaćanje doprinosa, pa se javlja razlika u doprinosima.

Nakon isplate akontacije, po pristiglim mesečnim obračunskim listama sa prilozima, pristupa se konačnom obračunu. Prilikom konačnog obračuna, utvrđuje se činjenično stanje gde su, usled velikog broja lica, moguće situacije sa pogrešnom prijavom vrste prihoda (umesto naknade prijavljena je plata za rad i sl.), ili pogrešni sati efektivnog rada, ili pogrešni sati odsustva na teret poslodavca ili fonda, neopravdane isplate za lica kojima je prestao radni odnosa ili su započela odsustvo na teret fonda, a moguće su situacije da po sudskim nalozima treba obustaviti iznos koji je viši od preostalog dela za isplatu lica. Po završenom konačnom obračunu, sastavlja se mesečna rekapitulacija plate: 
Tabela 24 - Mesečna rekapitulacija plate

\begin{tabular}{|c|c|c|c|c|}
\hline Plata za rad & Dodatak za minuli rad & Dodatak za rad noću & $\begin{array}{l}\text { Dodatak za rad u } \\
\text { dane državnih } \\
\text { praznika koji nisu } \\
\text { radni dani }\end{array}$ & $\begin{array}{c}\text { Dodatak za } \\
\text { prekovremeni rad }\end{array}$ \\
\hline $1.217 .473 .664,65$ & $79.311 .952,41$ & $4.562 .134,25$ & $1.254 .789,24$ & $2.999 .128,74$ \\
\hline $\begin{array}{c}\text { Dodatak za dodatno } \\
\text { opterećenje }\end{array}$ & $\begin{array}{l}\text { Paušalni dodatak na } \\
\text { platu }\end{array}$ & $\begin{array}{l}\text { Dodatak za } \\
\text { pripravnost }\end{array}$ & $\begin{array}{l}\text { Naknada za vreme } \\
\text { udaljenja od rada }\end{array}$ & $\begin{array}{c}\text { Naknada plate za } \\
\text { vreme privremene } \\
\text { sprečenosti za rad } \\
\text { na teret poslodavca }\end{array}$ \\
\hline $270.585,99$ & $1.857 .456,88$ & $356.834,04$ & $1.453 .097,12$ & $43.666 .897,12$ \\
\hline $\begin{array}{l}\text { Naknada za } \\
\text { neiskorišćeni } \\
\text { godišnji odmor }\end{array}$ & $\begin{array}{l}\text { Naknada plate za } \\
\text { vreme korišćenja } \\
\text { godišnjeg odmora i } \\
\text { drugog plaćenog } \\
\text { odsustva }\end{array}$ & $\begin{array}{l}\text { Naknada plate za } \\
\text { vreme odsustva za } \\
\text { dane državnog } \\
\text { praznika }\end{array}$ & $\begin{array}{c}\text { Naknada plate za } \\
\text { vreme sprečenosti za } \\
\text { rad (bolovanja) na } \\
\text { teret Fonda }\end{array}$ & $\begin{array}{l}\text { Naknada plate za } \\
\text { odsustvo tokom } \\
\text { školovanja i } \\
\text { usavršavanja }\end{array}$ \\
\hline $156.487,23$ & $40.123 .456,89$ & $10.057 .896,23$ & $24.533 .094,68$ & $11.246 .915,64$ \\
\hline $\begin{array}{c}\text { Naknada plate za } \\
\text { neraspoređena lica }\end{array}$ & $\begin{array}{l}\text { Naknada plate za lica } \\
\text { na raspolaganju }\end{array}$ & $\begin{array}{c}\text { Dodatak na platu za } \\
\text { ostvarene rezultate u } \\
\text { radu }\end{array}$ & $\begin{array}{c}\text { Bruto (neto sa } \\
\text { porezom i } \\
\text { doprinosima na teret } \\
\text { zaposlenog }\end{array}$ & Neto \\
\hline $1.995 .708,24$ & $24.691 .397,58$ & 0,00 & 1.466.011.496,93 & $1.054 .478 .621,36$ \\
\hline Osnovica za porez & Osnovica za doprinose & $\begin{array}{c}\text { Dodatni doprinos } \\
\text { za PIO }\end{array}$ & Porez & Obustave \\
\hline 1.197.965.876,77 & $1.466 .145 .151,72$ & $84.473 .474,48$ & $119.796 .587,68$ & $132.945 .630,46$ \\
\hline $\begin{array}{c}\text { Doprinos za PIO na } \\
\text { teret zaposlenog }\end{array}$ & $\begin{array}{c}\text { Doprinos za } \\
\text { zdravstveno osiguranje } \\
\text { na teret zaposlenog }\end{array}$ & $\begin{array}{l}\text { Doprinos u slučaju } \\
\text { nezaposlenosti na } \\
\text { teret zaposlenog }\end{array}$ & $\begin{array}{l}\text { Zbirni doprinosi na } \\
\text { teret zaposlenog }\end{array}$ & Neto za isplatu \\
\hline $205.260 .321,24$ & $75.506 .475,31$ & $10.996 .088,64$ & $291.762 .885,19$ & $921.532 .990,90$ \\
\hline $\begin{array}{c}\text { Doprinos za PIO na } \\
\text { teret poslodavca }\end{array}$ & $\begin{array}{c}\text { Doprinos za } \\
\text { zdravstveno osiguranje } \\
\text { na teret poslodavca }\end{array}$ & $\begin{array}{l}\text { Doprinos u slučaju } \\
\text { nezaposlenosti na } \\
\text { teret zaposlenog }\end{array}$ & $\begin{array}{l}\text { Zbirni doprinosi na } \\
\text { teret poslodavca }\end{array}$ & \begin{tabular}{|c|} 
Cena koštanja (Bruto \\
sa doprinosima na \\
teret poslodavca)
\end{tabular} \\
\hline $175.937 .418,21$ & $75.506 .475,31$ & $10.996 .088,64$ & $346.913 .456,64$ & $1.812 .951 .550,87$ \\
\hline
\end{tabular}


U mesečnoj rekapitulaciji plate i naknada obračunati su pripadajući iznosi u skladu sa propisanim načinom primene odgovarajućih osnovica i drugih propisa. Osnovica za doprinose se uobičajeno razlikuje od bruto prihoda, pri čemu, ukoliko razlika između bruto prihoda i osnovice doprinosa kod slučajeva primene najviše mesečne osnovice za plaćanje doprinosa zbirno premašuje ukupnu razliku između osnovice doprinosa i bruto prihoda kod slučajeva primene najniže osnovice, ukupan bruto prihod iznosiće više od zbirne osnovice za plaćanje doprinosa. U gornjem primeru, osnovica za plaćanje doprinosa viša je od bruto prihoda, zbog lica koja su primila određenu naknadu koja bruto iznosi niže od najniže mesečne osnovice za plaćanje doprinosa, kao i zbog lica kojima nije isplaćena plata ni naknada plate a postoji obaveza za plaćanje doprinosa po najnižoj mesečnoj osnovici. Upravo zbog slučajeva kada se bez isplate neto naknade isplaćuju samo doprinosi po najnižoj mesečnoj osnovici, ili kada se kod obračuna plate po bruto osnovici u izvođenju najniže mesečne osnovice za plaćanje doprinosa primenjuju posebni propisi, dolazi do odstupanja u jednačini da neto proizilazi iz razlike između bruto prihoda, poreza i doprinosa na teret zaposlenog, odnosno da je cena koštanja zbir bruto prihoda i doprinosa na teret poslodavca.

Za isplatu konačnog (preostalog) dela plate i naknada, pripremljena je PPPO koja u primeru po rekapitulaciji sadrži sledeće iznose:

\begin{tabular}{|c|c|c|c|c|c|c|c|}
\hline Bprihod & Osn. Porez & Porez & Osn. Dopr & PIO & Zdr. osig & NZS. & Ben. Staž \\
\hline $793.722 .438,98$ & $659.541 .981,47$ & $65.954 .198,15$ & $775.340 .451,90$ & $201.588 .517,50$ & $79.860 .066,55$ & $11.630 .106,78$ & $44.997 .361,32$ \\
\hline
\end{tabular}

Poreska prijava za isplatu konačnog dela trebalo bi da predstavlja prostu razliku između konačnog obračuna $\mathrm{i}$ isplaćene akontacije, međutim, u praksi je viša usled više razloga. Kod budžetskih korisnika, razlozi su delom zbog tehničkih ograničenja u podnošenju poreskih prijava, ${ }^{3}$ a delom i usled nemogućnosti da se već isplaćena sredstva (prilikom akontacije) po jednom osnovu (nameni ekonomske klasifikacije) kroz sistem izvršenja budžeta mogu preknjižiti na drugi osnov po kojem su se trebala isplatiti. ${ }^{4}$

\footnotetext{
${ }^{3}$ Čest uzrok pretplate poreza i doprinosa javlja se kod prijave prihoda za lica koja rade na poslovima gde se staž računa sa uvećanim trajanjem. Ako se prilikom isplate akontacije za lice ne prijavi i ne isplati doprinos za beneficirani staž na prvi deo plate, onda se zbog upisa benificiranog staža u konačnoj prijavi mora prijaviti cela plata kako bi se uplatio odgovarajući staž, usled čega dolazi do pretplaćivanja poreza i doprinosa za redovan staž osiguranja (istovremeno se podnosi izmenjena akontaciona prijava gde se za to lice brišu prihod, porezi i doprinosi u vezi sa prvim delom plate).

${ }^{4}$ Ukoliko se prilikom akontacije isplati deo naknade za privremenu sprečenost za rad do 30 dana (knjiži se po kontu 411117 kod budžetskih korisnika), a nakon dostavljanja doznake se uvidi da je trebalo isplatiti deo naknade za privremenu sprečenost za rad preko 30 dana (knjiži se po kontu 414112, na teret fonda), pošto su ranije isplaćena sredstva sprovedena kroz sistem izvršenja budžeta ne može se izvršiti preknjižavanje, te se onda vrši prijava celog prihoda na ime predmetne naknade (radi podnošenja zahteva za refundaciju prema fondu), s tim da se deo neto iznosa koji je ranije isplaćen licu na tekući račun, sada prenosi na račun izvršenja budžeta (da se ne bi duplo isplaćivao deo neto naknade), a za deo pretplaćenih poreza i doprinosa se podnosi zahtev za povraćaj ili zahtev za preknjižavanje na sledeću poresku obavezu.
} 


\section{Tendencija kretanja stope poreza i doprinosa}

Od početka primene, do poslednjih izmena i dopuna Zakona o porezu na dohodak građana i Zakona o doprinosima za obavezno socijalno osiguranje stope poreza i doprinosa, kretale su se prema sledećoj tabeli:

Tabela 25 - Pregled stopa poreza i doprinosa na teret zaposlenog i poreskih olakšica na zaradu za zaposlene, bez dodatnih poreskih olakšica za posebne slučajeve i kategorije lica

\begin{tabular}{|c|c|c|c|c|c|c|c|c|}
\hline \multicolumn{2}{|c|}{ Period primene } & \multirow{2}{*}{$\begin{array}{l}\text { koef. za } \\
\text { preračun }\end{array}$} & \multirow{2}{*}{$\begin{array}{l}\text { Zbirna } \\
\text { stopa }\end{array}$} & \multirow{2}{*}{$\begin{array}{l}\text { poreska } \\
\text { olakšica }\end{array}$} & \multirow[b]{2}{*}{ porez } & \multicolumn{3}{|c|}{ doprinosi na teret zaposlenog } \\
\hline od & do & & & & & $\begin{array}{c}\text { dopr. za } \\
\text { PIO }\end{array}$ & $\begin{array}{c}\text { dopr. za } \\
\text { zdrav. } \\
\text { osig. }\end{array}$ & $\begin{array}{c}\text { dopr. za } \\
\text { nezap. }\end{array}$ \\
\hline 1.6 .2001 & 30.4 .2003 & 0,697 & $30,30 \%$ & 0 & $14,00 \%$ & $9,80 \%$ & $5,95 \%$ & $0,55 \%$ \\
\hline 1.5 .2003 & 30.6 .2004 & 0,692 & $30,80 \%$ & 0 & $14,00 \%$ & $10,30 \%$ & $5,95 \%$ & $0,55 \%$ \\
\hline 1.7 .2004 & 31.12 .2006 & 0,681 & $31,90 \%$ & 0 & $14,00 \%$ & $11,00 \%$ & $6,15 \%$ & $0,75 \%$ \\
\hline 1.1.2007 & 31.1 .2008 & 0,701 & $29,90 \%$ & 5.000 & $12,00 \%$ & $11,00 \%$ & $6,15 \%$ & $0,75 \%$ \\
\hline 1.2 .2008 & 31.1 .2009 & 0,701 & $29,90 \%$ & 5.560 & $12,00 \%$ & $11,00 \%$ & $6,15 \%$ & $0,75 \%$ \\
\hline 1.2 .2009 & 31.1 .2010 & 0,701 & $29,90 \%$ & 5.938 & $12,00 \%$ & $11,00 \%$ & $6,15 \%$ & $0,75 \%$ \\
\hline 1.2 .2010 & 31.1 .2011 & 0,701 & $29,90 \%$ & 6.554 & $12,00 \%$ & $11,00 \%$ & $6,15 \%$ & $0,75 \%$ \\
\hline 1.2 .2011 & 31.1 .2012 & 0,701 & $29,90 \%$ & 7.310 & $12,00 \%$ & $11,00 \%$ & $6,15 \%$ & $0,75 \%$ \\
\hline 1.2 .2012 & 31.1 .2013 & 0,701 & $29,90 \%$ & 7.822 & $12,00 \%$ & $11,00 \%$ & $6,15 \%$ & $0,75 \%$ \\
\hline 1.2 .2013 & 29.5.2013 & 0,701 & $29,90 \%$ & 8.776 & $12,00 \%$ & $11,00 \%$ & $6,15 \%$ & $0,75 \%$ \\
\hline 30.3 .2013 & 31.1 .2014 & 0,701 & $29,90 \%$ & 8.776 & $10,00 \%$ & $13,00 \%$ & $6,15 \%$ & $0,75 \%$ \\
\hline 1.2 .2014 & 31.7 .2014 & 0,701 & $29,90 \%$ & 11.000 & $10,00 \%$ & $13,00 \%$ & $6,15 \%$ & $0,75 \%$ \\
\hline 1.8.2014 & 31.1 .2015 & 0,701 & $29,90 \%$ & 11.000 & $10,00 \%$ & $14,00 \%$ & $5,15 \%$ & $0,75 \%$ \\
\hline 1.2 .2015 & 31.1 .2016 & 0,701 & $29,90 \%$ & 11.433 & $10,00 \%$ & $14,00 \%$ & $5,15 \%$ & $0,75 \%$ \\
\hline 1.2 .2016 & 31.1 .2017 & 0,701 & $29,90 \%$ & 11.604 & $10,00 \%$ & $14,00 \%$ & $5,15 \%$ & $0,75 \%$ \\
\hline
\end{tabular}


Tabela 26 - Pregled stopa doprinosa na teret poslodavca

\begin{tabular}{|c|c|c|c|c|c|c|c|c|}
\hline \multicolumn{2}{|c|}{ Period primene } & \multicolumn{7}{|c|}{ doprinosi na teret poslodavca } \\
\hline od & do & $\begin{array}{c}\text { dopr. za } \\
\text { PIO }\end{array}$ & $\begin{array}{c}\text { dopr. za } \\
\text { zdrav. } \\
\text { osig. }\end{array}$ & $\begin{array}{c}\text { dopr. za } \\
\text { sluč. } \\
\text { nezap. }\end{array}$ & $\begin{array}{c}\text { dopr. za } \\
\text { staž sa } \\
\text { uveć. traj. } \\
12 / 14\end{array}$ & $\begin{array}{c}\text { dopr. za } \\
\text { staž sa } \\
\text { uveć. traj. } \\
12 / 15\end{array}$ & $\begin{array}{c}\text { dopr. za } \\
\text { staž sa } \\
\text { uveć. traj. } \\
12 / 16\end{array}$ & $\begin{array}{c}\text { dopr. za } \\
\text { staź sa } \\
\text { uveć. traj. } \\
12 / 18\end{array}$ \\
\hline 1.6.2001 & 30.4 .2003 & $9,80 \%$ & $5,95 \%$ & $0,55 \%$ & $3,30 \%$ & $4,90 \%$ & $6,50 \%$ & $9,80 \%$ \\
\hline 1.5 .2003 & 30.6 .2004 & $9,80 \%$ & $5,95 \%$ & $0,55 \%$ & $3,30 \%$ & $4,90 \%$ & $6,50 \%$ & $9,80 \%$ \\
\hline 1.7 .2004 & 31.12 .2006 & $11,00 \%$ & $6,15 \%$ & $0,75 \%$ & $3,70 \%$ & $5,50 \%$ & $7,30 \%$ & $11,00 \%$ \\
\hline 1.1 .2007 & 31.1 .2008 & $11,00 \%$ & $6,15 \%$ & $0,75 \%$ & $3,70 \%$ & $5,50 \%$ & $7,30 \%$ & $11,00 \%$ \\
\hline 1.2 .2008 & 31.1 .2009 & $11,00 \%$ & $6,15 \%$ & $0,75 \%$ & $3,70 \%$ & $5,50 \%$ & $7,30 \%$ & $11,00 \%$ \\
\hline 1.2 .2009 & 31.1 .2010 & $11,00 \%$ & $6,15 \%$ & $0,75 \%$ & $3,70 \%$ & $5,50 \%$ & $7,30 \%$ & $11,00 \%$ \\
\hline 1.2 .2010 & 31.1 .2011 & $11,00 \%$ & $6,15 \%$ & $0,75 \%$ & $3,70 \%$ & $5,50 \%$ & $7,30 \%$ & $11,00 \%$ \\
\hline 1.2 .2011 & 31.1 .2012 & $11,00 \%$ & $6,15 \%$ & $0,75 \%$ & $3,70 \%$ & $5,50 \%$ & $7,30 \%$ & $11,00 \%$ \\
\hline 1.2 .2012 & 31.1 .2013 & $11,00 \%$ & $6,15 \%$ & $0,75 \%$ & $3,70 \%$ & $5,50 \%$ & $7,30 \%$ & $11,00 \%$ \\
\hline 1.2 .2013 & 29.5 .2013 & $11,00 \%$ & $6,15 \%$ & $0,75 \%$ & $3,70 \%$ & $5,50 \%$ & $7,30 \%$ & $11,00 \%$ \\
\hline 30.3 .2013 & 31.1 .2014 & $11,00 \%$ & $6,15 \%$ & $0,75 \%$ & $3,70 \%$ & $5,50 \%$ & $7,30 \%$ & $11,00 \%$ \\
\hline 1.2 .2014 & 31.7.2014 & $11,00 \%$ & $6,15 \%$ & $0,75 \%$ & $3,70 \%$ & $5,50 \%$ & $7,30 \%$ & $11,00 \%$ \\
\hline 1.8.2014 & 31.1 .2015 & $12,00 \%$ & $5,15 \%$ & $0,75 \%$ & $3,70 \%$ & $5,50 \%$ & $7,30 \%$ & $11,00 \%$ \\
\hline 1.2 .2015 & 31.1 .2016 & $12,00 \%$ & $5,15 \%$ & $0,75 \%$ & $3,70 \%$ & $5,50 \%$ & $7,30 \%$ & $11,00 \%$ \\
\hline 1.2 .2016 & 31.1.2017 & $12,00 \%$ & $5,15 \%$ & $0,75 \%$ & $3,70 \%$ & $5,50 \%$ & $7,30 \%$ & $11,00 \%$ \\
\hline
\end{tabular}

Do kraja 2006. godine, zbirna stopa poreza i doprinosa na teret zaposlenog imala je rastući trend, da bi se početkom 2007. godine snizila, od kada se nije menjala. Takođe, od 2007. godine uvedena je poreska olakšica, koja se godišnje uvećavala prema stopi rasta cena na malo u kalendarskoj godini koja je prethodila godini u kojoj se usklađivanje vrši.

U ovakvom poreskom okruženju sa tendencijom povećanja poreske olakšice, s obzirom da neto osnovica za obračun plate nema veću stopu rasta od bruto osnovice za obračun plate, zaposleni kojima se plata obračunava po bruto osnovici nastaviće ostvarivati veće pravo na penzijsko osiguranje u odnosu i na račun zaposlenih kojima se plata obračunava po neto osnovici. 


\section{Izbor najpovoljnije metode za obračun plate}

Uzimajući u obzir postojeći način obračuna poreza i doprinosa iz plate i trend kretanja poreske stope, stopa doprinosa i poreskih olakšica, metoda obračuna plate po neto osnovici odgovara poslodavcima, jer ostvaruju uštede po osnovu poreskog rasterećenja. Sa druge strane, metoda obračuna plate po bruto osnovici odgovara zaposlenima, koji uz svako novo poresko rasterećenje ostvaruju izvesno uvećanje neto plate i veće penzijsko osiguranje. U slučaju pooštravanja fiskalnih nameta, uvećanja poreske stope ili stopa doprinosa, smanjenja poreskih olakšica, metoda obračuna plate po bruto osnovici odgovarala bi poslodavcu usled nepromenjenog troška bruto plate (eventualno bi se uvećao trošak po osnovu doprinosa na teret poslodavca, ali bi ukupan trošak plate po bruto osnovici bio niži u odnosu na to da je plata obračunavana po neto osnovici) dok bi metoda obračuna plate po neto osnovici pogodovala zaposlenima, kojima bi se u tom slučaju uvećavao penzijski osnov.

Ukoliko bi se za sve zaposlene kod budžetskih korisnika uveo obračun plate po neto osnovici (prelaz sa bruto na neto osnovicu najverovatnije bi se izvršio množenjem bruto iznosa sa koeficijentom 0,701 ), zaposleni u privrednom sektoru kojima se zarada obračunava po bruto osnovici ostvarivali bi veće pravo na penzijsko osiguranje na uštrb zaposlenih kojima se plate/zarade obračunavaju po neto osnovici, što bi se dalje uvećavalo novim poreskim olakšicama, ili smanjenjem poreske stope, ili smanjenjem stope doprinosa za zdravstveno osiguranje, ili smanjenjem stope doprinosa za slučaj nezaposlenosti, a što ne bi trebalo da utiče na visinu prava na penzijsko osiguranje lica (osim kada je u pitanju promena stope doprinosa za penzijsko osiguranje).

Zaokret u poreskoj reformi i eventualni prelaz na neto princip obračuna poreza i doprinosa, tj. na neto zaradu/platu uz odgovarajuću nivelaciju neto odnosno bruto osnovice za obračun plate/zarade, značajno bi uprostio obračun poreskih obaveza. Izmena sadašnjeg načina obračuna penzije, tako što bi se godišnja neto zarada/plata lica stavljala u odnos sa godišnjom prosečnom neto zaradom u R. Srbiji, odakle bi se dalje izvodio lični koeficijent, onemogućila bi da poresko rasterećenje na posredan način negativno utiče na penzijsko osiguranje velikog broja zaposlenih, odnosno sprečio bi se negativni uticaj smanjenja stope doprinosa (za zdravstveno osiguranje i u slučaju nezaposlenosti). Međutim, isto bi takođe dovelo do smanjenja javnih prihoda po osnovu poreza i doprinosa na zarade, najmanje u visini $25 \%$, što je neodrživo sa nivoom trenutnih javnih rashoda.

Prema podacima iz Fiskalne strategije Vlade za 2016. godinu sa projekcijama za 2017. i 2018. godinu (tabela 5.: Prihodi, rashodi i rezultat sektora države u 2015. godini budžet i procena zasnovana na trećoj reviziji aranžmana sa MMF) javni prihodi po osnovu poreza na dohodak (čiji najveći deo čini porez na zarade) i doprinosa skoro dvostruko prevazilaze prihode po osnovu poreza na dobit pravnih lica (koji predstavlja primarni izvor javnih prihoda u razvijenim ekonomijama, tzv. „corporate tax"). Uzrok ovakvog stanja nije dovoljno tražiti u slabim rezultatima privrednih subjekata, nego treba analizirati i rashodnu stranu po osnovu poreza i doprinosa na zarade. Nasleđeni model dvostrukog zaračunavanja doprinosa po istoj osnovici u slučaju prosečne neto zarade za februar 2016. godine (44,450 dinara) generiše trošak na ime poreza i doprinosa u visini 17.304,06 dinara, ili 38,92\% neto zarade. Drugim rečima, na svakih 100 dinara prosečne neto zarade iz februara 2016. godine obračunava se 38,92 dinara fiskalnih davanja, što predstavlja značajno opterećenje. 
Zagovornici progresivnog oporezivanja, predlažu agresivniju poresku politiku na visokim zaradama. Na primer, da se poreska olakšica odredi najmanje u visini prosečne mesečne potrošačke korpe, uz povećanje poreske stope za oporezivanje zarade/plate za iznose iznad prosečne mesečne potrošačke korpe (prosečna potrošačka korpa za februar 2016. iznosi 67.150,62 dinara), čime bi se težiše fiskalnih nameta sa minimalnih zarada odnosno zarada ispod prosečne mesečne potrošačke korpe premestilo na visoke zarade. Međutim, ovakvo materijalno rešenje bi smanjilo bruto plate/zarade po neto osnovici na nivou prosečne mesečne potrošačke korpe za najmanje deset procentnih poena, što bi se negativno odrazilo na individualno penzijsko osiguranje.

\section{Zaključak}

U radu je izloženo teorijsko i praktično izučavanje poreskih implikacija u zavisnosti od metoda obračuna plate kod budžetskih korisnika, pri čemu se izvedeni zaključci odnose podjednako na sektor države i privrede. Korišćena je komparativno-deskriptivna metoda, metoda slučaja, metoda analize i sinteze, induktivna metoda, metoda apstrakcije i generalizacije.

Polazeći od ranijih i novijih naučnih saznanja u oblasti obračuna i poreskog administriranja zarada/plata, razmatranja principa u knjigovodstvenom obuhvatanju primanja u privredi i kod budžetskih korisnika, proučavanjem sistema obračuna zarade, poreskih procedura i segmenata penzijskog osiguranja, preko pomoćnih hipoteza do zaključnih razmatranja, u radu se nastojalo ukazati na određene aspekte koji su bili zanemareni u dosadašnjim merama konsolidacije javnih finansija.

Analiza slučaja kod metoda obračuna plate kroz efekte promene poreskih komponenata pokazala je rezultate kojima se dovodi u pitanje smisao ugrađenih rešenja u sadašnjem modelu obračuna poreza i doprinosa na trenutne zarade. Naime, mehanizmi promene elemenata poreskog sistema ili sistema obračuna plate u sprezi sa sistemom penzijskog osiguranja su trenutno neusklađeni i u zavisnosti od situacije, jedna kategorija lica ostvaruje koristi na štetu druge. Logično je zapitati se, da li usled nepromenjene visine neto zarade (plate) i stope doprinosa za penzijsko i invalidsko osiguranje, a promenom drugih poreskih elemenata i stopa doprinosa, treba da se menja visina prava iz penzijskog osiguranja?

Dejstvo poluge poreskog sistema između sistema obračuna zarada i sistema socijalnog osiguranja može se prepoznati upravo kod dvostrukog modela obračuna plate. Stanovište da promena jedne komponente poreskih elemenata uz nepromenjenu visinu ostalih srazmerno utiče na visinu prava u određenom domenu osiguranja ne stoji. Najpovoljniji način obračuna plate trenutno se ne može odrediti usled neusklađenosti poreskog sistema, sistema obračuna zarade i sistema penzijskog odnosno socijalnog osiguranja.

\section{Literatura}

[1] Arsić M, Ranđelović S, Altiparmakov N. et al, Poreska politika u Srbiji - pogled unapred, FREN, 2010.

[2] Vukša S. i dr, Poreska i budžetska kontrola i revizija, EtnoStil, Beograd, 2011.

[3] IFAC, Međunarodni računovodstveni standardi za javni sektor, prevod SRRS, 2011. Jezdimirović M, Efikasnost budžetskog sistema Srbije, Univerzitet Singidunum, Beograd, 2011.

[4] Kulić M, Milošević G, Poresko pravo - teorija i praksa, Marso, Beograd, 2011. 
[5] Ministarstvo finansija Republike Srbije, Fiskalna strategija za 2016. godinu sa projekcijama za 2017. i 2018. godinu,

http://www.mfin.gov.rs/UserFiles/File/dokumenti/2015/Fiskalna\%20strategija\%20za\%202016_\%20 godinu\%20sa\%20projekcijama\%20za\%202017_\%20i\%202018_\%20godinu.pdf.

[6] Ministarstvo finansija Republike Srbije, Konceptualni okvir za finansijsko izveštavanje, http://www.mfin.gov.rs/UserFiles/File/MRS/2014/Konceptualni\%20okvir.pdf.

[7] Međunarodni računovodstveni standard 19 - Primanja zaposlenih, („Službeni glasnik RS“, broj 35/2014) ili www.mfin.gov.rs/UserFiles/File/MRS/2014/IAS/IAS\%2019.pdf, 15.02.2016.

[8] Pravilnik o poreskoj prijavi za porez po odbitku, „Službeni glasnik RS“, broj 74/13, 118/13, 66/14 i 71/14.

[9] Pravilnik o standardnom klasifikacionom okviru i kontnom planu za budžetski sistem (,Službeni glasnik RS“, broj 103/2011, 10/2012, 18/2012, 95/2012, 99/2012, 22/2013, 48/2013, 61/2013, 63/2013 - ispr., 106/2013, 120/2013, 20/2014, 64/2014, 81/2014, 117/2014, 128/2014, 131/2014, 32/2015, 59/2015, 63/2015 i 97/2015).

[10] Raičević B, Javne finansije, Ekonomski fakultet u Beogradu, 2010.

[11] Uredba o budžetskom računovodstvu, „Službeni glasnik RS“, broj 125/2003 i 12/2006.

[12] Uredba o primeni Međunarodnih računovodstvenih standarda za javni sektor, „Službeni glasnik RS“, broj 49/2010.

[13] Škarić-Jovanović, K, Računovodstvo, Beogradska poslovna škola, Beograd, 2005.

[14] Zakon o budžetu Republike Srbije za 2016. godinu „Službeni glasnik RS“, broj 103/15

[15] Zakon o budžetskom sistemu „Službeni glasnik RS“, broj 54/2009, 73/2010, 101/2010, 101/2011, 93/2012, 62/2013, 63/2013, 108/2013, 142/2014, 68/2015 - dr. zakon i 103/2015.

[16] Zakon o Vojsci Srbije „Službeni glasnik RS“, broj 1162007, 88/2009, 101/2010, 10/2015 i 88/2015.

[17] Zakon o doprinosima za obavezno socijalno osiguranje „Službeni glasnik RS“, br. 84/2004, 61/2005, 62/2006, 5/2009, 52/2011, 101/2011, 7/2012 - usklađeni din. izn., 8/2013 - usklađeni din. izn., 47/2013, 108/2013, 6/2014 - usklađeni din. izn., 57/2014, 68/2014 - dr. zakon, 5/2015 usklađeni din. izn., 112/2015 i 5/2016 - usklađeni din. izn.

[18] Zakon o penzijskom i invalidskom osiguranju („Službeni glasnik RS“, br. 34/03, 64/04, 84/04, 85/05, 101/05, 63/06, 5/09, 107/09, 101/10, 93/12, 62/13, 108/13, 75/14 i 142/14).

[19] Zakon o platama državnih službenika i nameštenika „Službeni glasnik RS“, br. 62/2006, 63/2006 - ispr., 115/2006 - ispr., 101/2007, 99/2010, 108/2013 i 99/2014.

[20] Zakon o poreskom postupku i poreskoj administraciji, „Službeni glasnik RS“, br. 80/02, 84, 23/03, 70/03, 55/04, 61/05, 85/05, 62/06, 63/06, 61/07, 20/09, 72/09, 53/10, 101/11, 2/12, 93/12, $47 / 13,108 / 13,68 / 14,105 / 14,91 / 15$ i 112/15.

[21] Zakon o porezu na dohodak građana, „Službeni glasnik RS“, br. 24/2001, 80/2002, 80/2002 - dr. zakon, 135/2004, 62/2006, 65/2006 - ispr., 31/2009, 44/2009, 18/2010, 50/2011, 91/2011 - odluka US, 7/2012 - usklađeni din. izn., 93/2012, 114/2012 - odluka US, 8/2013 usklađeni din. izn., 47/2013, 48/2013 - ispr., 108/2013, 6/2014 - usklađeni din. izn., 57/2014, 68/2014 - dr. zakon, 5/2015 - usklađeni din. izn., 112/2015 i 5/2016 - usklađeni din. izn.)

[22] Zakon o porezu na dobit pravnih lica „Službeni glasnik RS“, br. 25/2001, 80/2002, 80/2002 - dr. zakon, 43/2003, 84/2004, 18/2010, 101/2011, 119/2012, 47/2013, 108/2013, 68/2014 - dr. zakon, 142/2014, 91/2015 - autentično tumačenje i 112/2015.

[23] Zakon o radu, „Službeni glasnik RS“, broj 24/2005, 61/2005, 54/2009, 32/2013 i 75/2014.

[24] Zakon o računovodstvu, „Službeni glasnik RS“, broj 62/2013.

[26] Zakonu o sistemu plata zaposlenih u javnom sektoru, „Službeni glasnik RS“, broj 18/2016. 